\title{
The Vertical Distribution of Marine Macroplankton. IX. The Distribution of the Pelagic Young of Teleostean Fishes in the Daytime in the Plymouth Area.
}

By

F. S. Russell, D.S.C., B.A.,

Naturalist at the Plymouth Laboratory.

With 7 Figures in the Text.

\section{CONTENTS.}

INTRODUCTION

General Results . . . . . . . . . . . . 642

The Difference in Behaviour between Post-larvæ of Spring and of Summer Spawners . .5 .6 .0 .646

A Comparison between the Catches of the Bottom Plankton Net and those of the Oblique Hauls with the Two-metre Ring-trawl . . . 647

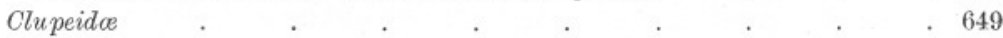

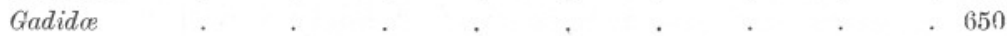

Caproida . . . . . . . . . . . . 654

Bothidee . . . . . . . . . 654

Pleuronectidae. . . . . . . . . 655

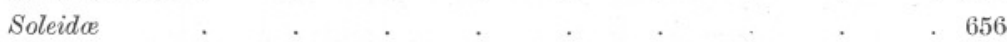

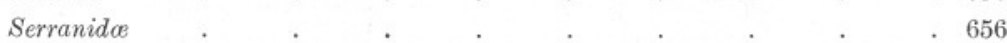

Carangidae . . . . . . . . . . . 656

Scombresocida . . . . . . . . 657

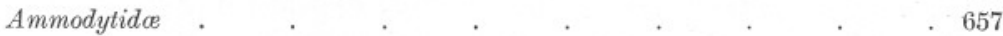

Cepolida $\quad . \quad . \quad . \quad . \quad . \quad . \quad . \quad . \quad .657$

Callionymidae . . . . . . . . . . . . . 657

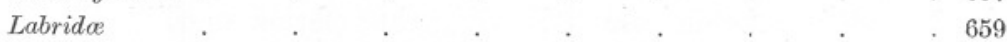

Trachinidae . . . . . . . . . . . . . 659

Scombridae . . . . . . . . . . . 660

Zeida . . . . . . . . 661

Gobiida . . . . 661

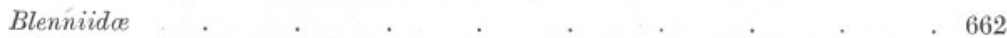

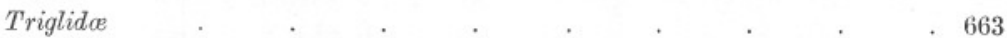

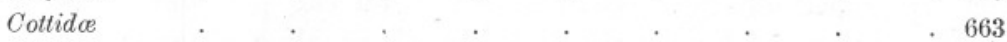

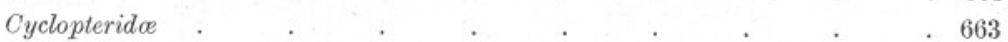

Gobiesocida . . . . . . . . . . . . . . . 664

Lophiidae . . . . . . . . . . . . . 664

Summary

References .

664

665

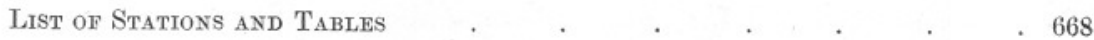




\section{INTRODUCTION.}

IN continuation of the study of the vertical distribution of the pelagic young of Teleostean fishes, already reported on for 1924 and 1925 (1), a further fifteen stations were made with the two-metre stramin net in the daytime between April and September in 1926. The collections were made in a manner exactly similar to that for those of the previous years, hauls of ten minutes' duration being made almost always at six different depths with the net towed horizontally as near as possible at the same speed on each occasion. The Admiralty depth-recording instrument was used at every station, and the results for each haul are given in Figures 6 and 7 on pages 666 and 667 , which show the graphic records of the path of the net through the water for each haul. (That for June 25th is not included, an unsatisfactory record being obtained on that day owing to the drum of the recorder not having been fully screwed down, see 4, p. 431.)

Nearly all the collections were made in the same locality, namely, about two miles east of the Eddystone Lighthouse, in water of a depth of about 54 metres. (This position is known in this and previous papers as "A".)

The full details as to the time of day, weather conditions, depths of hauls, etc., are given in the log on page 668 at the end of the report.

Previous research had indicated that possibly some species may have lived in the daytime in water layers nearer the bottom than had been sampled by the ring-trawl. Accordingly the work has been supplemented in 1927 and 1928 by collections made with the bottom plankton net described in a previous publication (5), and, for comparison, oblique hauls made with the two-metres ring-trawl fishing in the water layers from a depth of about 35 metres up to the surface itself. In making the oblique hauls the net has been fished at six different depths using exactly the same lengths of wire as have been used for the serial hauls in the previous years. The net was fished for five minutes at each depth, the necessary amount of wire being wound in after that period until the six depths including the surface had been fished. On two occasions the depth recorder was in use, and Figure 1 shows the path of the net through the water on these occasions. In the first case, June 29th, 1927, the maximum depth reached was 30 metres, and on July 8th, 1927, it was 46 metres. These depths probably represent the limits within which the maximum depth reached on each occasion lies: in all the previous collections to study the vertical distribution of the plankton, the maximum depth of the deepest haul has usually been between these depths. When possible the collections with the bottom plankton net and those of the oblique hauls were made on the same day; one haul being made with the ring-trawl at Station A, and three with the bottom net, viz. at A, at the International Hydrographic Station L4, and at a position about 2 miles W.S.W. of the 
Rame Head on a muddy bottom. Altogether 36 oblique hauls with the ring-trawl and 114 hauls with the bottom plankton net were made. The data for these catches are necessarily bulky and are not being published; they have been carefully examined, and it is considered sufficient for the present purpose that they should be given as in Tables 5 and 6, pages 675-6, namely, as average monthly catches only. The total number of fish caught in any one month has been divided by the total number of hauls for that month. On page 642 are given the dates

METRES.

METRES.

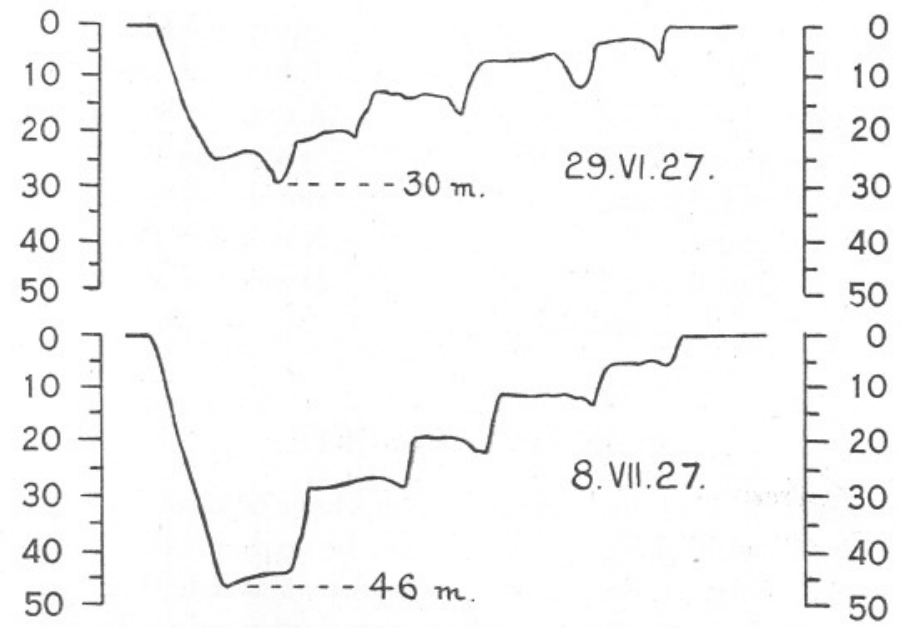

FIG. 1.-Tracings given by the depth-recorder indicating the path of the ring-trawl through the water for the half-hour oblique hauls on June 29 th, 1927, and July 8th, 1927. The net enters the water on the right-hand side of each curve.

on which the various collections were made. All the collections were made in daylight.

In compiling Table 5, giving the average monthly catches for the bottom plankton net, the actual figures have been multiplied by 8.5 to bring them as nearly comparable to the oblique ring-trawl figures as possible. The bottom plankton net was so constructed that the area of its mouth was $1 / 8 \cdot 5$ that of the two-metre ring-trawl $\left(5^{*}\right.$, p. 107$)$.

It is with pleasure that I acknowledge my indebtedness to Capt. V. Lord and the crew of the s.s. Salpa for their co-operation and assistance in making the collections.

* I am greatly indebted to Mr. J. S. Colman for pointing out an error in this publication (5, p. 107). In line 23, "fishing area " should read "circumference," and in line 25 , "a quarter" should read $\frac{1}{8 \cdot \overline{5}}$ : on the following pages, therefore, 8.5 should be read in place of 4 on each occasion and the necessary corrections made. 


\section{Dates of Collections with Ring-trawl and Bottom Plankton Net.}

\author{
Bottom-stramin net, \\ 30 -minute hauls at three \\ different stations. \\ 1928. January 3, 11, 17, 26 \\ February 3, 10, 14, 24, 29 \\ March 8, 23, 30. \\ April 12, 18, 23, 24, 30 \\ May 11,17
}

1927. June 2, 29

July 8, 15

August 5, 12, 19, 25, 31

September 6, 15, 20, 30

October 4, 13, 18, 25

November 1

December 6, 15, 2]

114 hauls.
Ring-trawl, 30-minute oblique hauls 2 miles East of the Eddystone.

January 9, 16, 26, 30

February 2, 20, 27

March 5, 21, 30

April 4, 11, 12, 23

June 2, 9, 29

July $8,12,21,26$

August 4, 8, 19, 26, 31

September 6, 15, 19

October 4, 13, 18, 24

November 1

December 15, 21

36 hauls.

\section{GENERAL RESULTS.}

The general results of the above collections have confirmed and extended those previously published. There can now be no doubt that the different species of fish differ markedly in the depths at which their post-larvæ are to be found most abundantly in the daytime in the waters off Plymouth.

It would appear to be possible to place our post-larval fishes under the following headings as regards their vertical distribution in the daytime on a sunny day in waters of 50 metres depth off Plymouth during the months in which they are most abundant. When a note of interrogation (?) appears after the name of a fish, it implies that the number of individuals caught of that species are not sufficient to be considered significant, and the indications only are that the fish may come under the category in which it is placed.

Most abundant from surface layers down to 5 to 10 metres.

Gadus pollachius (Pollack); Blennius gattorugine (Tompot Blenny); Labridæ (Wrasses); Rhombus sp. (Brill and Turbot) (?).

Abundant at all depths, but mostly above 25 to 30 metres and sometimes avoiding the actual surface.

Onos sp. (Rockling); Arnoglossus sp. (Scaldbacks); Scomber scomber (Mackerel); Trachinus vipera (Lesser Weaver); Caranx trachurus (Horse Mackerel). 
Abundant below 15 metres, and falling off in numbers below 30 to 35 metres.

There is a tendency for the following species which come under this category to show slight differences in their preference of depth, becoming successively deeper in the following order (see Fig. 2) :

Scophthalmus norvegicus (Ekstrom's Topknot); Pleuronectes flesus (Flounder) (?); Gadus merlangus (Whiting); Solea vulgaris (Sole) (?); Pleuronectes limanda (Dab); Solea variegata (Thickback); Trigla spp. (Gurnards); Callionymus sp. (Dragonets), deeper in June and July than in April and May; Pleuronectes microcephalus (Merrysole); G. luscus (?) (Pouting); Molva molva (Ling) (?); Merluccius merluccius (Hake) (?); Zeugopterus punctatus (?); Lebetus scorpioides (?).

Becoming abundant below 20 to 25 metres, with maximum abundance probably very near bottom.

Gadus minutus (Bib or Poor Cod); Gobius spp. (Gobies); Lepadogaster bimaculatus (?); Cottus bubalis (Bullhead) (?).

Irregular in their type of distribution, though usually avoiding the actual surface.

Clupeid spp. (Sprat and Pilchard), when present in daytime; Ammodytes spp. (Sandeels).

A certain elasticity must be allowed in a scheme like this where one is dealing with a population of living animals in their natural environment ; but it seems legitimate to say that on a clear sunny day, with the sea surface calm, just before midday, such would be the vertical distribution of the post-larvæ of the above fish in water of 50 metres depth off Plymouth in the months when the respective fish are most abundant.

An average vertical distribution, in the case of those species whose post-larvæ have been numerously represented in the collections on several occasions, has been estimated by superimposing all the diagrams so far obtained giving the actual vertical distribution of the fish in question on sunny days; that is, by tracing through, one over the other, each vertical distribution diagram that has been obtained. From this superimposition of figures an average vertical distribution for the species has been drawn freehand and is shown in Figure 2. The accuracy of these diagrams has been checked by working out the average catch of each fish on sunny days for every five metres depth from the total of all the collections made in 1925 and 1926. On the top half of Figure 2 are given the vertical distribution diagrams which can be expected on sunny days during the months of April and May for the commoner species found here whose chief spawning period lies in the spring. On the lower half of the figure similar diagrams are given for the vertical distribution of the post-larval stages of those whose spawning period lies in the summer months and whose postlarvæ are most abundant in June, July and August. The data for these 

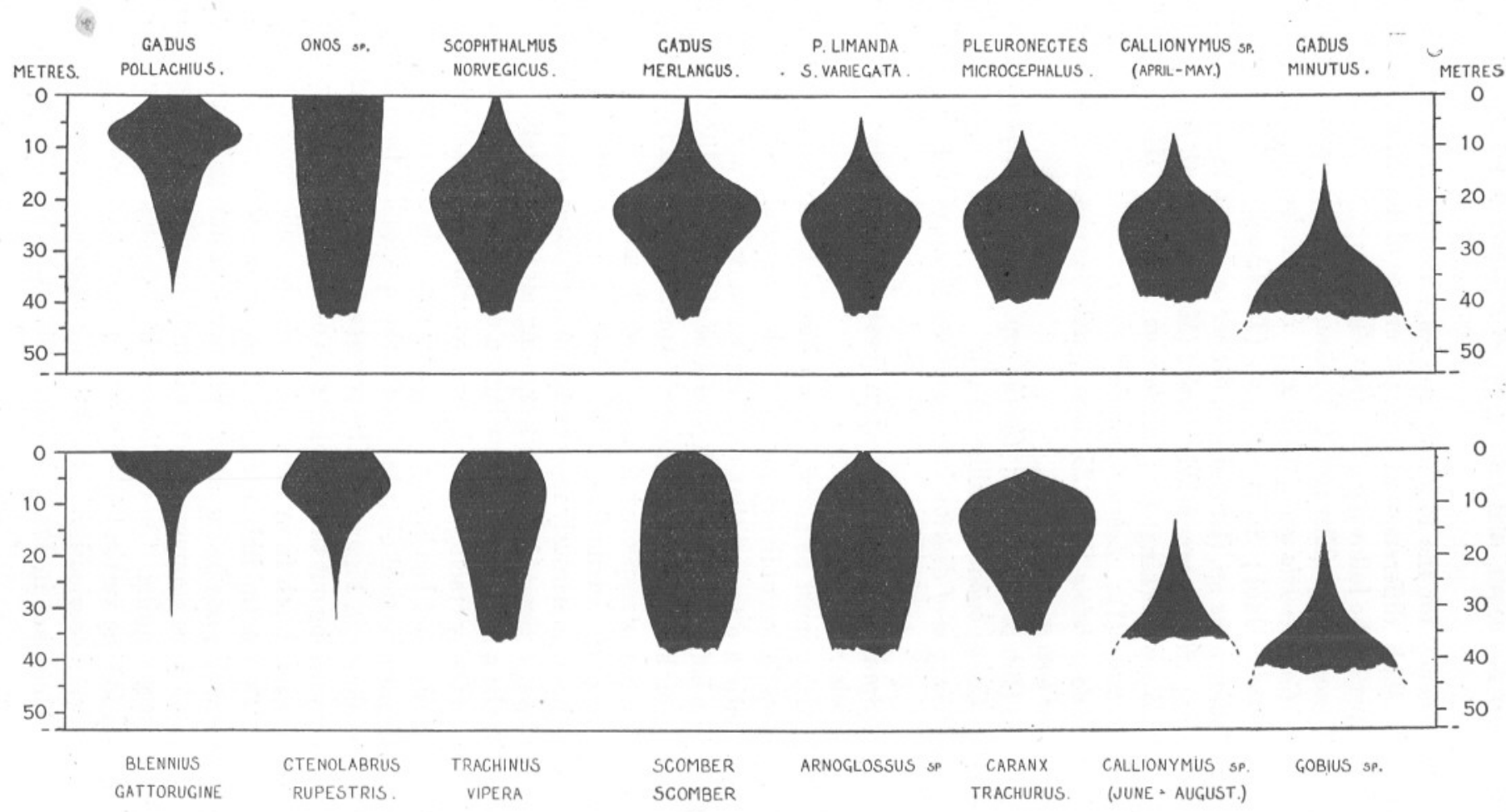

FIG. 2.-Average vertical distribution for the post-larvæ of the above species during the months when they are most abundant on sunny days just before noon in water 54 metres deep off Plymouth. The upper half shows the expected vertical distribution for the postlarvæ of certain spring-spawners; while the lower half shows that for some summer-spawners. 
latter are by no means so definite as are those for the post-larval stages of the spring spawners ; the numbers of times on which they have been taken in sufficient numbers to give significant results are few, and in one or two cases (e.g. Trachinus vipera and Caranx trachurus) the figures are based on one result only. It is a general rule that the summer forms are not nearly so abundant as the spring forms.

While the above scheme can be taken as holding for the conditions stated, namely, a sunny day before noon, with a calm sea, there are certain factors which operate to affect such distributions under the same conditions, and other conditions which give rise to changed distributions during the day and from one day to the next. These factors are :-

1. Dull weather.

2. Time of day.

3. Abundance of other plankton organisms.

4. Nearness to coast.

1. Dull weather. There are definite indications that in dull weather certain species of post-larvæ are higher in the water than on sunny days. While the number of observations made on dull days are fewer than those made on sunny days, there is nevertheless a certain consistency to be found in the results.

For example, in Figure 4, page 658, the upward trend in the vertical distribution of Callionymus post-larvæ can be seen between the days April 22nd (Sunny) and April 26th (Dull), as also between May 6th (Sunny) and May 19th (Dull) ; the same also can be seen for other species of fish in this and the previous paper (1).

2. Time of day. The majority of the observations recorded here represent the results of collections made between the hours of 10 a.m. and 12 noon (G.M.T.) (see List of Stations, p. 668). Figures 3, page 652, and 4 , page 658 , show, however, in the case of Gadus merlangus post-larvæ and of those of Callionymus the vertical distribution at two periods during the day. On April 13th, 13.iv.26 (i) represents the results of the collections made between 11.3 a.m. and 12.38 p.m., while the $13 . i v .26$ (ii) hauls were between 1.40 p.m. and 2.51 p.m. ; the surface haul was taken in the first case at $11.3 \mathrm{a} . \mathrm{m}$. and in the second at 2.51 p.m., and the bottom hauls at 12.38 p.m. and 1.40 p.m. respectively. It can be seen that there has been a quite definite, though slight, move upwards in the vertical distribution of these species between the morning and afternoon observations.

Any alterations caused by the passage from daylight to darkness have been recorded in previous papers ( 2 and 3 ).

3. Abundance of other plankton organisms. There have on several occasions been indications that certain changes in the normal vertical 
distribution of post-larval fishes may be found correlated with extreme abundance of certain other plankton animals in the surface layers.

The following occasions have already been recorded. On May 19th, 1925 (1, p. 109), the occurrence of post-larvæ of Gadus merlangus, Scophthalmus norvegicus, Solea variegata, and Callionymus sp., at the surface was noticed to coincide with the presence of a dense swarm of the megalopas of Corystes cassivelaunus in the surface layers. In another locality on the same day, where the megalopas were scarce in the surface layers, the post-larvæ of the above-mentioned species exhibited a normal vertical distribution.

On June 4th, 1926 (3, pp. 833 and 841), post-larvæ of Scophthalmus norvegicus, Solea variegata, and Callionymus sp., were very much higher in the water than on the previous day; this was correlated with the presence of very dense swarms of Calanus finmarchicus in the surface layers.

On August 4th, 1926, the numbers of post-larvæ taken in the surface layers were unusually large, and on this day the swarms of Calanus on the surface were exceptional (4, p. 432).

4. Nearness to coast. It has already been shown $(\mathbf{1}$, p. 108) that " the post-larvæ of many species of fish become abundant at much smaller depths below the surface close inshore over shallow water than they do a few miles from the coast over depths of 50 metres or more."

\section{The Difference in Behaviour Between Post-Larve of Spring and of Summer Spawners.}

Figure 2 shows up a very striking general result that has arisen from the observations of 1926 supplemented with those of previous years. This is that there appears to be a fundamental difference between the behaviour of the post-larvæ of the spring spawners and that of the post-larval stages of the summer spawners. While the majority of the post-larvæ of spring spawners (with the exception of those of Gadus pollachius and of Onos sp.) tend to be below 15 metres in the daytime with their maximum numbers at 20 metres or deeper, those of the summer spawners seem to prefer the upper layers and are usually most numerous above 25 metres, except such forms as Gobius spp. and Lepadogaster bimaculatus.

The significance of this is not understood. The summer spawners are mostly representatives of warm-water fish on whose northern limit of distribution this region lies or whose distribution is affected by the movements of the warm waters of the Gulf Stream Drift. Possibly in the latitudes in which they are most prevalent they live deeper, although, owing to the greater sunlight in those latitudes, they may experience normally higher intensities of light than do the cold-water forms in their normal 
habitat. These intensities are only to be found in the upper layers in this region. On the other hand, it may be that the preference for the upper layers is conditioned by temperature, and in these layers the highest temperatures are to be found.

\section{A Comparison between the Catches of the Bottom Plankton Net and those of the Oblique Hauls with the Two-metre RING-TRAWL.}

Between June, 1927, and May, 1928, 114 hauls were made with the bottom plankton net, and 36 oblique hauls with the two-metre ring-trawl. The results of these catches have been expressed in Tables 5 and 6 , pages 675 and 676 , as average monthly catches (see p. 643) ; in these tables the 1928 hauls have been placed before those of 1927 so that the results show conveniently the sequence of a regular calendar year. Unfortunately in 1928 there were no oblique-haul collections made during the month of May ; in the table, however, are given for that month the average halfhourly catches for the five years 1924, 1925, 1926, 1927, and 1929.

During the course of the researches on the vertical distribution of plankton it had become evident that certain forms, e.g. Clupeid post-larvæ and Tomopteris helgolandica, were not being taken in numbers in the daylight catches although night collections showed that they were really present in abundance in the region investigated. The natural conclusion was that such forms lived in the daytime in layers deeper than those normally sampled by the ring-trawl, that is somewhere between 35 metres and the bottom at about 54 metres. In order to obtain definite evidence on this point the net described in a previous publication (5) was employed.

The area of the mouth of the ring-trawl was 8.5 times that of the bottom plankton net, and the results shown in Table 5 are therefore the actual results multiplied by $8 \cdot 5$.

In most cases where the normal distribution has been shown by previous ring-trawl collections to be well up in the water it would be expected that the comparable bottom plankton net hauls would provide catches less than, or at any rate never greatly exceeding, those of the obliquelyhauled ring-trawl. Such has proved to be the case when the species in question have occurred in the catches in sufficient numbers to give significant results. Those forms which normally live high in the water up to the surface layers naturally appeared in far fewer numbers in the bottom plankton net than in the oblique hauls, e.g. Gadus pollachius post-larvæ were 25.9 times more numerous in the oblique hauls than in those of the bottom net, and in the case of Scomber scomber this figure was $7 \cdot 3$. 
It has already been pointed out that the post-larval sprats and pilchards became ten to thirty times as numerous in the dark as in the daytime in the ring-trawl catches ( 3, p. 835), and in the 24 -hour series of observations made in 1926 there were indications that these Clupeids moved down to levels below those sampled in the daytime. It was hoped, therefore, that the results of the collections with the bottom stramin net might settle this point. Examination of Table 6, page 676, shows, however, that the average catch for any month with the oblique ring-trawl sometimes exceeds, and sometimes is less than, that with the bottom plankton net, the total number for the year being approximately the same in the ring-trawl as in the bottom net. The evidence that the post-larval clupeids seek the actual layers next to the bottom is therefore negative. The possibility remains that they do not actually hug the bottom, but swim two or three metres above it, in which case a net with a much deeper mouth must be employed. There is one other possible explanation for their absence in the daytime catches, that is that in the daytime they are shoaling and only if the net actually passes through a shoal will the post-larvæ appear in any quantity in a catch; whereas at night the shoals break up and certain numbers are bound to be caught in all layers (2, p. 401).

While these researches have not definitely furthered our information on the habits of post-larval Clupeids, they have produced striking evidence on the behaviour of two other kinds of fish, namely, the post-larvæ of Gadus minutus (the Bib or Poor Cod) and those of Gobius spp.

Previous daylight observations on the vertical distribution of Gadus minutus showed that they lived always below about 30 metres. The fact also that at the lowest depths sampled their numbers were still increasing indicated that possibly the region of maximum abundance lay still deeper and had not been sampled. The results with the bottom plankton net show that, while the smaller post-larvæ are about as numerous near the bottom as they are in the oblique hauls, those of $12 \mathrm{~mm}$. length and over have congregated in great numbers right close to the bottom itself.

In a previous paper $(1$, p. 108) it had been pointed out that the postlarval Gobies in the collections in 1925 were extremely few compared with those of 1924, and it had been suggested that they were indeed scarce that year. Night observations showed, however, a considerable increase in their numbers, and the results of the bottom plankton net have revealed their presence quite close to the bottom in the daytime in great quantities. Rather similar results were shown also for post-larvæ of Lepadogaster bimaculatus although their numbers were very much smaller.

In the foregoing pages are briefly given the observations for each species for the recent collections and the conclusions drawn from these and the previous collections already published $(\mathbf{1}, \mathbf{2}$, and $\mathbf{3})$. In Tables 1 , 
2,3 , and 4 at the end of the paper are to be found the numbers of fish of each species caught during the course of the investigations.

\section{CLUPEID $Æ$.}

Clupea sprattus L. (Sprat) and Sardina pilchardus (Walb.) (Pilchard).

Figure 4, page 658 , shows the results of the vertical distribution observations for these species in 1926; while the earlier catches can be taken to consist mostly of sprat, those of the later months will be mostly pilchard.

These observations confirm the previous conclusions that these postlarvæ, 4-20 mm. long, when caught in the daylight appear to be distributed rather indiscriminately. At the same time, series of observations which have been made at night ( 2 and 3 ) show that the daytime distribution cannot be a true picture of the habits of the majority of these Clupeid post-larvæ since they increase in number 10 to 30 times in the catches at night.

It was hoped that the results of the bottom plankton net collections would throw light on this question by showing an increased number in the bottom layers. Tables 5 and 6 (pp. 675 and 676) show, however, that while in six months in the year more were taken in the ring-trawl oblique hauls than in the bottom plankton net, in the other six months the reverse was the case. Actually, taking the total of the monthly averages for the year, approximately the same number were taken in the ring-trawl as in the bottom plankton net, and in June and July, the months in which a marked increase in numbers has been shown in the upper layers at night, there were 9 and $10 \cdot 6$ times as many in the ring-trawl as on the bottom. It should here be mentioned that the postlarvæ occurring in the catches from January to the beginning of March will be mostly those of Clupea harengus, the Herring, and there is perhaps an indication in the March hauls of their being near the bottom; but in this case, and in other months when the bottom plankton net catches exceed those with the ring-trawl, nothing like the striking differences were found as were shown in the case of Gadus minutus, the Gobies, or Lepadogaster bimaculatus.

It would therefore seem that the true behaviour of Clupeid postlarvæ remains yet to be shown. It is possible that the bottom plankton net samples too narrow a layer above the bottom and that some net fishing a metre or more above the sea bottom may show the presence of these young fish in abundance in the daytime. Alternatively; as mentioned above on page 648 , the post-larvæ may shoal in the daytime, the shoals breaking up at night. 


\section{GADIDÆ.}

\section{Gadus pollachius L. (Pollack).}

In the 1926 collections few only of this species were taken, and these indiscriminately at all depths. There was no evidence that they avoided the surface layers, and the conclusions based on these and the previous observations would seem to be that they may be taken at all depths, but are on the whole more numerous actually in the surface layers. The postlarvæ in question are from 4 to $10 \mathrm{~mm}$. in length.

The collections in the oblique hauls with the ring-trawl in April, 1928, showed a fairly high average of $21 \cdot 6$ specimens per haul against the low average of 0.9 in the bottom plankton net, confirming that they are not abundant in the layers near the bottom.

\section{Gadus merlangus L. (Whiting).}

Figure 3 shows diagramatically the results of the 1926 collections. They confirm the conclusion previously stated that the majority of whiting post-larvæ, 5 to $12 \mathrm{~mm}$. in length, live below 15 metres, although the seasonal change suggested in the previous report was not shown so markedly. The rise of these young fish in the water on May 19th is no doubt due to the fact that the day was very dull.

All results can be summarised as follows :-

Post-larvæ 5-12 mm. mostly below 15 metres; region of maximum abundance 20 to 30 metres, falling off in numbers considerably below 35 metres.

Post-larvæ 12-50 mm. in association with Cyanea, living at the depths that the Cyanea are in the daytime and following their migrations at night.

Ratio oblique hauls with ring-trawl : bottom plankton net $=7 \cdot 5: 1$.

\section{Gadus minutus (O. F. Müll.) (Bib or Poor Cod).}

The 1926 results (Figure 3) confirm the fact that post-larvæ of the poor cod, 4-10 $\mathrm{mm}$. in length, are the deepest living of the common Plymouth gadoids, being most abundant almost always well below 20 metres.

Further light is shown on their behaviour by the collections made with the bottom plankton net. Below are given the numbers caught in halfhour oblique hauls with the ring-trawl and the average catches for three half-hour hauls on each day with the bottom plankton net. 
Ring Trawl (Oblique).

$\begin{array}{cr}\text { February 27th } & 12 \\ \text { March 5th } & 29 \\ \text {, 21st } & 14 \\ \text {, 30th } & 30 \\ \text { April 4th } & 166 \\ \text {, 11th } & 120 \\ \text {, 23rd } & 65\end{array}$

Bottom Plankton Net.*

$\begin{array}{cc}\text { February 29th } & - \\ \text { March 8th } & 36 \cdot 6 \\ ,, \quad 23 \mathrm{rd} & 17 \\ \text { ", 30th } & 385 \cdot 1 \\ \text { April 12th } & 229 \cdot 5 \\ \text {, 18th } & 133 \cdot 5 \\ \text {, 23rd } & 138 \cdot 6 \\ \text {, 24th } & \\ \text { " 30th } & 3689 \\ \text { May 11th } & 3034 \cdot 5 \\ \text {, 17th } & 325 \cdot 6\end{array}$

It can be seen from the above figures that up to April 23rd the numbers of post-larval poor cod taken in the bottom plankton net are on the whole greater than those taken in the oblique hauls with the ring-trawl, but after that date there is an enormous increase in the numbers caught in the bottom net, though unfortunately there are no catches with the ring-trawl for comparison.

An examination of the following table, which gives the lengths in millimetres of the fish taken on various dates, shows very definitely that this increase in numbers is due to a sudden descent to the bottom of fish from the layers above.

Length in millimetres.

$\begin{array}{llllllllllllllllllllllll}4 & 5 & 6 & 7 & 8 & 9 & 10 & 11 & 12 & 13 & 14 & 15 & 16 & 17 & 18 & 19 & 20 & 21 & 22 & 23 & 24 & 25 & 26 & 27\end{array}$

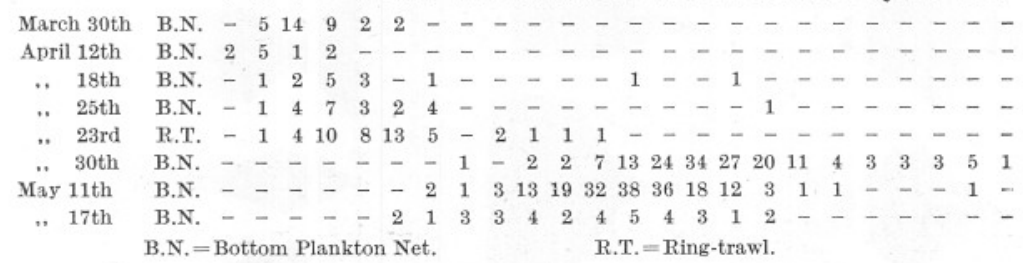

In all previous collections it appears that the post-larval poor cod disappear from the catches at a length of between 10 and $12 \mathrm{~mm}$. In the previous publication $(1$, p. 119) it is said, "The majority of post-larvæ caught were between 5 and $10 \mathrm{~mm}$. in length, and there is no evidence of any differentiation in the distribution of the various sizes within these lengths ; for those above $10 \mathrm{~mm}$., however, there is an indication that they live deeper down."

Here we have definite evidence that there is a sudden descent of the young fish to the layers immediately above the bottom soon after the

\footnotetext{
* Average of catches at three stations on each day, multiplied by 8.5 for comparison with ring-trawl.
} 

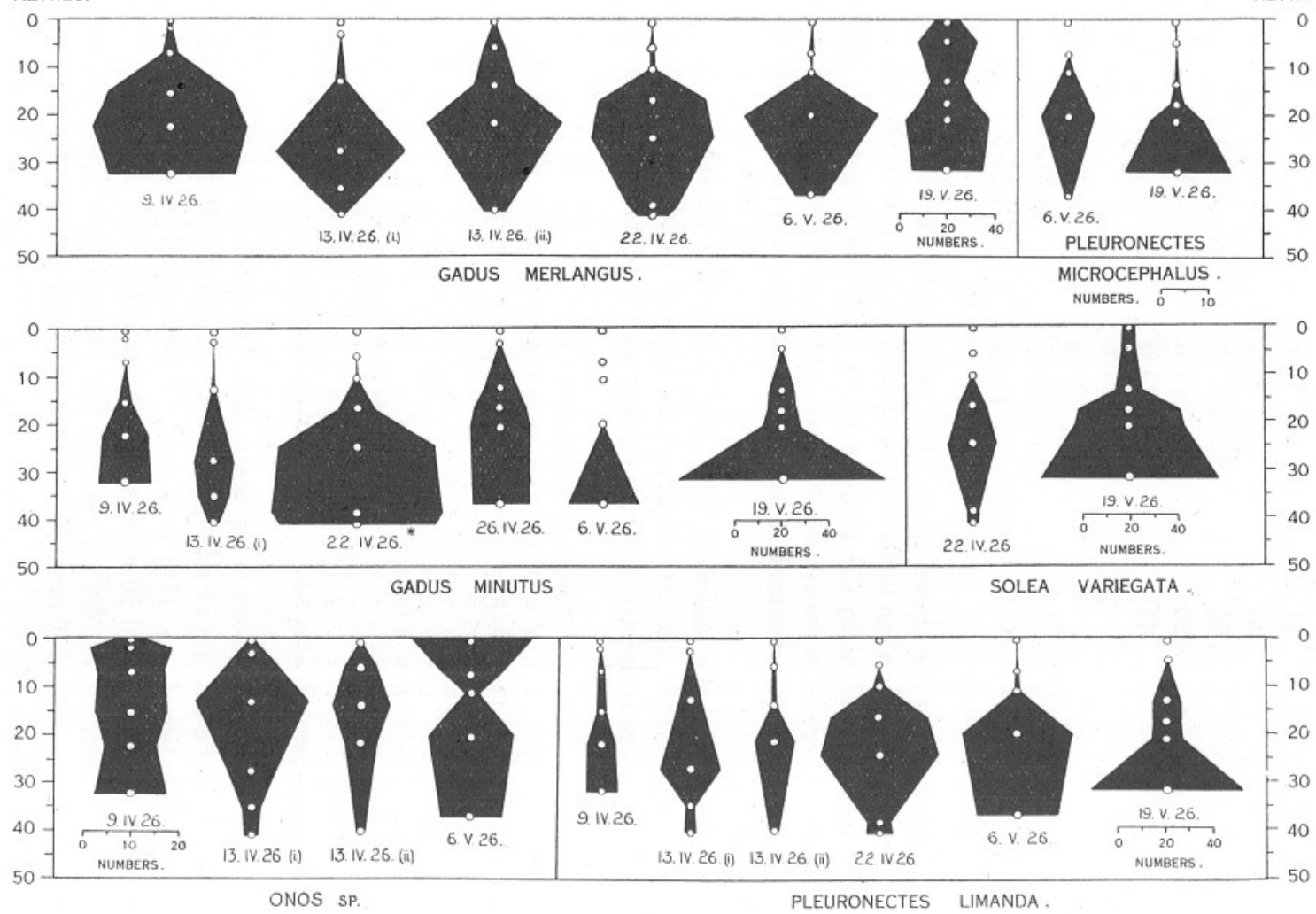

FIG. 3.-The vertical distribution of post-larvæ of the above species on the dates given. The white spots and black circles indicate the "average depths" at which hauls were taken. "Gadus minutus, on 22. iv. 26, is drawn to half the scale of the others. 
fish has reached 10-12 mm. in length ; the majority of fish in the bottom net catches on April 30th were between 12 and $21 \mathrm{~mm}$. long, and the largest was $27 \mathrm{~mm}$. It is possible that above this length they are fully able to avoid capture by the slow-moving net.

Summary of results :

Post-larvæ 4-12 mm., chiefly in water layers between 20-25 metres and the bottom.

Post-larvæ 12-27 mm. in water layers immediately above the bottom. Ratio, oblique hauls with ring-trawl : bottom plankton net $=1: 13 \cdot 9$.

\section{Gadus Luscus L. (Pouting).}

Post-larvæ of this species were not abundant in the 1926 catches, the main breeding period lying possibly between December and April. Altogether $74^{*}$ post-larvæ, mostly between 4 and $8 \mathrm{~mm}$. long, were taken, and of these one was taken from between the surface and 10 metres, 9 between 10 and 20 metres, 34 between 20 and 30 metres, and 30 between 30 and 41 metres, confirming the 1925 results which pointed to the post-larvæ of the pouting being deep-living.

Ratio, oblique hauls with ring-trawl : bottom plankton net $=1 \cdot 8: 1$.

\section{Gadus callarias L. (Cod).}

A few post-larvæ of the cod, 5 to $8 \mathrm{~mm}$. in length, occurred in the catches during April in 1926, but the numbers were too low to be significant. Altogether 4 specimens were taken above 10 metres, 9 between 10 and 20 metres, 3 between 20 and 30 metres, and 5 between 30 and 41 metres, the largest catch being 8 at $15 \cdot 5$ metres on April 9 th.

\section{ONos sP. (Rockling).}

Figure 3 shows the results of the collections in 1926. These confirm the previous conclusions that Onos post-larvæ are to be found at all depths with a slight preference for the surface layers. The post-larvæ in question are 4-10 mm. in length, and after this size they are to be found always in large numbers congregated under masses of drifting weed.

Ratio, oblique hauls with ring-trawl : bottom plankton net $=4 \cdot 1: 1$.

\section{Molva molva L. (Ling).}

Only a few post-larvæ of this species were taken, but these were all but one from below 15 metres; this confirms the previous observations.

None were taken in the bottom plankton net.

* On this and all succeeding occasions the numbers taken in the daylight on June 3rd4 th are included (3, Table X, p. 850) although they are not repeated in Table 2. 


\section{Merluccius merluccius L. (Hake).}

Post-larvæ of the hake were only taken on July 26th, 1926, when 4 specimens, 4 to $5 \mathrm{~mm}$. in length, were caught, 2 at 18.5 metres, one at 28.7 metres, and one at $35 \cdot 1$ metres ; and on June $3 \mathrm{rd}$, when one specimen, $5.5 \mathrm{~mm}$. long, was taken at 31.5 metres.

Ratio, oblique haul with ring-trawl : bottom plankton net $=1 \cdot 9: 1$.

\section{Raniceps Raninus L. (Lesser Forkbeard).}

Only five post-larvæ of this species, $4-6 \mathrm{~mm}$. in length, were caught in 1926 , one at $43 \cdot 1$ metres on June 25 th, two at $40 \cdot 7$ metres on July 13 th, and one each at 21.5 and $34 \cdot 1$ metres respectively at E1 on July 15 th.

No post-larvæ of this species appeared in the bottom plankton net.

\section{CAPROID 伥.}

\section{Capros aper L. (Boarfish).}

Four post-larvæ only of this species were taken; one of $3 \frac{1}{2} \mathrm{~mm}$. from $13 \cdot 7$ metres at E1 on July 15th, and three of $4-4 \frac{1}{2} \mathrm{~mm}$. from $22 \cdot 2$ metres on August 4th.

No post-larvæ of this species appeared in the bottom plankton net.

\section{BOTHIDÆ.}

\section{Arnoglossus SP. (Scaldbacks).}

Figure 5, page 662, shows the results for Arnoglossus sp. post-larvæ, probably $A$. laterna (Will), on the three days on which they were at all numerous; but on this occasion, and in the previous year, the numbers were not great enough to allow conclusions to be drawn with safety. The indications are, however, that post-larvæ, 6 to $20 \mathrm{~mm}$. long, may occur at any depth, but there is generally a tendency to avoid the actual surface layers down to a depth of about 5 metres.

Ratio, oblique hauls with ring-trawl : bottom plankton net $=2 \cdot 2: 1$.

\section{- Rhombus spe. (Turbot and Brill).}

Post-larvæ of these species, Rhombus maximus Will. and $R$. lavis Rond., were never very numerous, but the indications were definitely that they preferred the upper layers above 10 metres and actually at the surface itself. Altogether 36 specimens were caught between the surface and 10 metres, 9 between 10 and 20 metres, one between 20 and 30 metres, and 5 between 30 and 40 metres. No post-larvæ of these species. occurred in the catches of the bottom plankton net. 
Scophthalmus noRvegicus (Günther), (Norway Topknot).

The only occasion on which this species was present in anything like its usual abundance was on June 3rd, 1926, when its distribution has already been reported $(3$, p. 841$)$. The small numbers caught on all other occasions, however, confirm the previous conclusions that post-larvæ, 4 to $10 \mathrm{~mm}$. in length, usually occur in greatest abundance below about 10 metres, being most numerous between 15 and 30 metres.

Ratio, oblique hauls with ring-trawl : bottom plankton net $=1 \cdot 2: 1$.

\section{Zeugopterus punctatus (Bloch.).}

Only very few post-larvæ of this species were taken ; on April 13th, one each at 21.6 and $40.1 \mathrm{~m}$.; on April $22 \mathrm{nd}$, one at $16.9 \mathrm{~m}$. and four at $24.6 \mathrm{~m}$. ; on April 26th, one at 12.6 metres and one at 16.7 metres; on May 6th, two at $37 \cdot 1$ metres, and on May 19 th, two at $17 \cdot 6$ metres and six at 32 metres. On June 3rd and 4th, 29 were caught, all below 10 metres depth. This confirms previous observations that these post-larvæ occur usually only below 10 metres and deeper.

Ratio, oblique hauls with ring-trawl : bottom plankton net $=2 \cdot 5: 1$.

\section{PLEURONECTID $\AA$.}

\section{Pleuronectes limanda L. (Dab).}

Figure 3 and the results given in Tables 1-4 confirm the previous conclusions that post-larval dabs, $5-13 \mathrm{~mm}$. in length, occur most abundantly below a depth of 15 to 20 metres.

Ratio, oblique hauls with ring-trawl : bottom plankton net $=1 \cdot 9: 1$.

\section{Plemononectes microcephalus (Don.), (Merrysole).}

Figure 3 and the results given in Tables $1-4$ confirm the previous conclusions that post-larval merrysoles, 4-13 mm. in length, occur most abundantly below a depth of 15 to 20 metres.

Ratio, oblique hauls with ring-trawl : bottom plankton net $=1 \cdot 7: 1$.

\section{Pleuronectes flesus L. (Flounder).}

Post-larvæ of the flounder, 4-9 mm. in length, were not very numerous in the catches, and of the total number caught 7 were from between the surface and 10 metres, 25 between 10 and 20 metres, 17 between 20 and 30 metres, and 13 between 30 and 41 metres. Thus it would seem that these post-larvæ occur slightly higher in the water than those of the dab, being already comparatively abundant at 10 metres.

Ratio, oblique hauls with ring-trawl to bottom plankton net $=4.5: 1$. 


\section{SOLEID $Æ$.}

Solea variegata (Don.), (Thickback).

Post-larvæ of the thickback, 4-10 mm. in length, as shown by Figure 3 and previous records have a vertical distribution similar to that of the dab, becoming most abundant below a depth of 15-20 metres.

Ratio, oblique hauls with ring-trawl : bottom plankton net $=4: 1$.

\section{Solea vulgaris (Quens.), (Common Sole).}

As in the previous year's collections the post-larvæ of the common sole were never very abundant in the 1926 catches. The largest catches were on April 22nd, when the majority lay below 10-15 metres.

Ratio, oblique hauls with ring-trawl : bottom plankton net $=1: 3 \cdot 7$.

\section{Solea lascaris Risso. (Sand Sole).}

Only one post-larva of this species, $6.5 \mathrm{~mm}$. in length, was taken, this being from $20 \cdot 1$ metres on July 13th. None were taken in the bottom plankton net.

\section{SERRANID E.}

\section{Serranus cabrilla L. (Sea Perch).}

Three post-larvæ of this species occurred in the catches ; one of $6 \mathrm{~mm}$. from 13.7 metres at E1 on July $15 \mathrm{th}$, and two of $4 \frac{1}{2}$ and $5 \mathrm{~mm}$. from 3.5 metres on August 4th.

\section{CARANGID $\nRightarrow$.}

\section{Caranx trachurus (L.), (Horse Mackerel).}

Post-larvæ of the horse mackerel, 4-15 mm. in length, only occurred in any numbers on August 4th (Fig. 5, p. 662). On this occasion while they were numerous at depths below 20 metres the greatest catch was from 9.5 metres. This seems to confirm the previous indications that the majority of the post-larvæ of this species are to be found above 20 metres. None were taken in the bottom plankton net. Below are given the actual sizes of the post-larvæ caught at each depth on August 4th. It can be seen that while the majority were between 4 and $10 \mathrm{~mm}$. in length, at 9.5 metres there were a few larger specimens up to as much as $15 \mathrm{~mm}$., although these were absent from other depths. In the same table are given the sizes of four of the medusa, Cyanea capillata, that were caught at the same time in the upper layers, and it seems very probable that the larger post-larvæ at 9.5 metres were in association with the large Cyanea which was 6 inches in diameter. 
August 4th, 1926

Surface (ii)

$3.5 \mathrm{~m}$.

$9.5 \mathrm{~m}$.

$22 \cdot 2 \mathrm{~m}$.

$28 \cdot 2 \mathrm{~m}$.

$39 \cdot 4 \mathrm{~m}$.
Length in millimetres.

$\begin{array}{rrrrrrrrrrrrc}4 & 5 & 6 & 7 & 8 & 9 & 10 & 11 & 12 & 13 & 14 & 15 & \\ - & 5 & 2 & - & - & - & 1 & - & - & - & - & - & 2^{\prime \prime} \\ - & - & - & 1 & - & - & - & - & - & - & - & - & 3^{\prime \prime} \\ 1 & 2 & 15 & 20 & 20 & 12 & 13 & 9 & 12 & 3 & 3 & 1 & 6^{\prime \prime}: 3^{\prime \prime} \\ - & 5 & 7 & 5 & 2 & 1 & - & - & 1 & 1 & - & - & - \\ - & 16 & 13 & 8 & 1 & - & - & - & - & - & - & - & - \\ 1 & 23 & 13 & 5 & - & - & - & - & - & - & - & - & -\end{array}$

\section{SCOMBRESOCID $Æ$.}

Belone vulgaris Flem. (Garfish).

One post-larval garfish, $22 \frac{1}{2} \mathrm{~mm}$. long, was taken at the surface on August 4th.

\section{AMMODYTID E.}

Ammodytes tobianus L. (Lesser Sandeel).

Post-larvæ of this species were taken in too small numbers to give a significant picture of their distribution, though the indication was that they showed no definite preference for any depth.

Ratio, oblique hauls with ring-trawl : bottom plankton net $=1 \cdot 5: 1$.

Ammodytes lanceolatus (Lesauv.), (Greater Sandeel).

Post-larvæ of this species, 5-20 mm. in length, were never very abundant, but what evidence there was confirmed the previous conclusions that they are somewhat irregularly distributed from the surface downwards with a tendency to avoid the actual surface layers.

Ratio, oblique hauls with ring-trawl $:$ bottom plankton net $=1: 1$.

\section{CEPOLID庄.}

\section{Cepola rubescens L. (Red Band Fish).}

Four post-larvæ of this species were taken on July 26th, two of $4 \frac{1}{2} \mathrm{~mm}$. from 18.5 metres, and one each of $4 \frac{1}{2}$ and $5 \mathrm{~mm}$. from $28 \cdot 7$ and $35 \cdot 1$ metres respectively. One of $3 \frac{1}{2} \mathrm{~mm}$. was taken at the surface on August 4th.

\section{CALLIONYMID压.}

\section{Callionymus spr. (Dragonets).}

Figure 4 shows the results of the collections of Callionymus post-larvæ in 1926; in the earlier months these will all be $C$. lyra (L.), but a few C. maculatus (Rafin.) will occur in the later collections. They confirm the previous conclusions that their region of maximum abundance lies below 20 metres. At the same time there is here definite evidence that in April and perhaps May the post-larvæ tend on the 

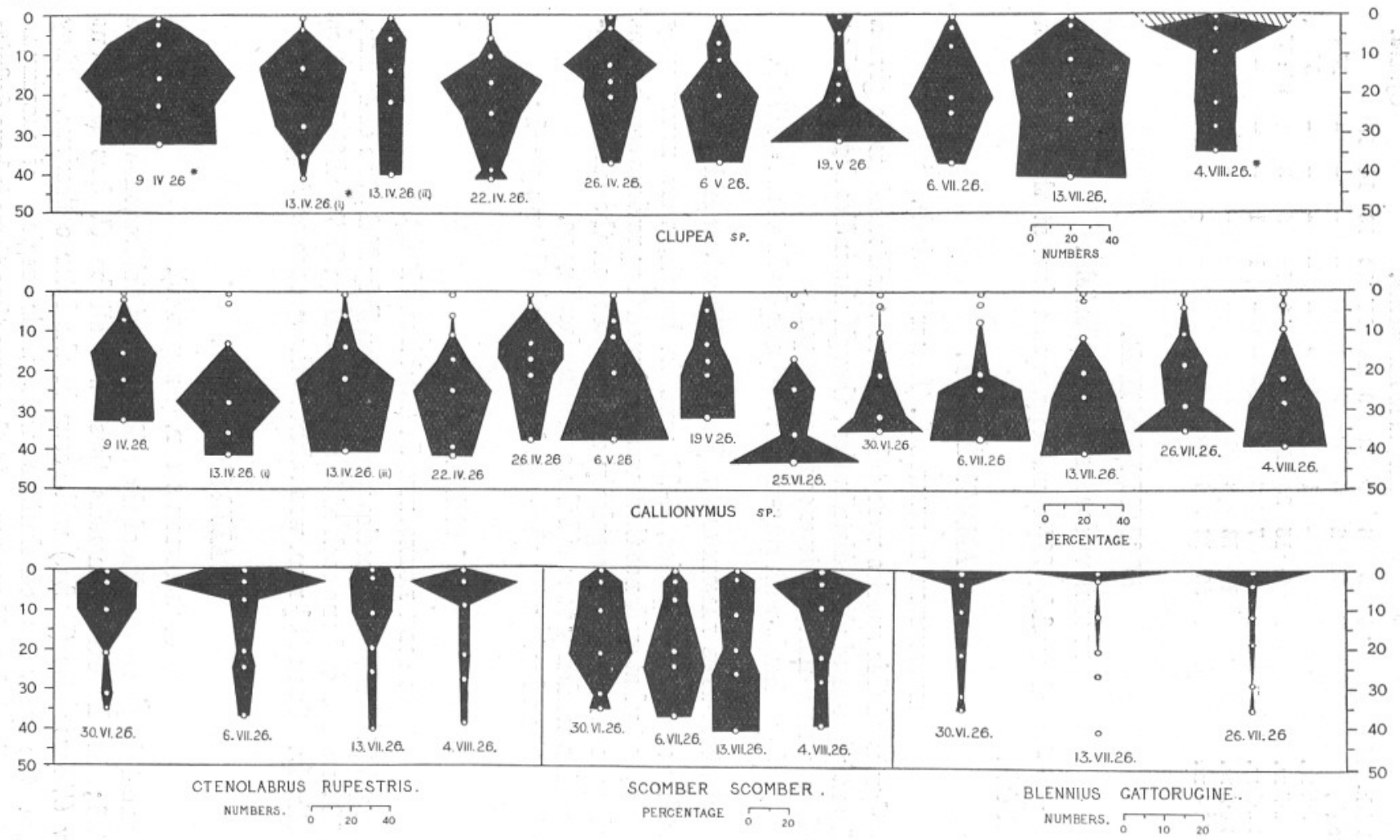

Fig. 4.-The vertical distribution of post-larvæ of the above species on the dates given. The white spots and black circles indicate the "average depths" at which hauls were taken. * Clupeid sp., on 9. iv. 26 ; 13. iv. 26 (i); and 4. viii. 26 , are drawn to half the scale of the others. 
whole to be higher in the water than in June, July, and August, because their numbers were still increasing with depth in the catches in these latter months, while in April the collections indicated that the region of maximum abundance had been fished through and their numbers were decreasing in the deepest hauls. See also Figure 2, p. 644, in which is given the average distribution in sunny weather as a result of superimposing all the records for April and May, and also those of June, July, and August.

Ratio, oblique hauls with ring-trawl : bottom plankton net $=2 \cdot 6: 1$.

\section{LABRID $\mathbb{E}$ (Wrasses).}

The post-larvæ of five species of wrasse appear in these collections : Labrus bergylta Asc., Labrus mixtus (L.), Crenilabrus melops (L.), Ctenolabrus rupestris (L.), and Centrolabrus exoletus (L.). It was concluded in $1925(1$, p. 130) that " all species showed a tendency to be most abundant above $20-25$ metres."

Although in 1926 Ctenolabrus rupestris was the only species present in any numbers, the following figures for the remaining species bear this out.

\begin{tabular}{lcccc} 
& \multicolumn{5}{c}{ Total numbers of post-larval wrasses caught. } \\
& Surface-10 m. & $10-20 \mathrm{~m}$. & $20-30 \mathrm{~m}$. & $30-45 \mathrm{~m}$. \\
Labrus bergylta & 36 & 32 & 23 & 23 \\
Labrus mixtus & 9 & 8 & 20 & 20 \\
Crenilabrus melops & 24 & 12 & 4 & 3 \\
Centrolabrus exoletus & 15 & 5 & 6 & 3
\end{tabular}

Of these Labrus mixtus would appear to be the exception, although they are not definitely absent from the upper layers; the few caught in the previous collections pointed to the majority being above 25 metres.

A figure showing the vertical distribution of $L$. bergylta post-larvæ has already been published (3, p. 846), when it was evident that the majority were at 10 metres or above.

As for the post-larvæ of Ctenolabrus rupestris, 4-8 $\mathrm{mm}$. in length, the diagrams shown in Figure 4 and the numbers represented in the catches in Tables 3 and 4 show conclusively that this form definitely prefers the upper layers, and is indeed most abundant above 10 metres and at the surface itself.

The ratios, oblique hauls with ring-trawl : bottom plankton net were :-

L. bergylta $1.4: 1$; L. mixtus $1.2: 1 ;$ C. melops $0.4: 1$; C. rupestris $1: 1$; and $C$. exoletus $3 \cdot 7: 1$.

\section{TRACHINID E.}

Trachinus vipera C. and V. (Lesser Weever).

Post-larvæ of this species, 4-7 mm. in length, were only numerous in the catches on August 4th (Fig. 5, p. 662). On this occasion it was very 
evident that, while they may be found at all depths, the post-larvæ showed a decided preference for the surface layers. This supports the indications given by the previous collections that they were most abundant above 25 metres.

Ratio, oblique hauls with ring-trawl : bottom plankton net $=3: 1$.

\section{SCOMBRID AE.}

Scomber scomber (L.), (Mackerel).

In 1925 (1, p. 133) the indications were that post-larval mackerel were most numerous above 25 metres. Post-larvæ of this species, mostly 4-10 mm. in length, were unusually abundant in 1926, and Figure 4 and Tables 3 and 4 show that we have quite definite evidence as to their vertical distribution. We see that they tended to be very evenly distributed from the surface downwards, though there was a tendency for the numbers to be slightly less actually at the surface itself.

Actually the greatest catches on each day were on June 30th at $21 \cdot 4$ metres, on July 6 th at $24 \cdot 7$ metres, on July 13 th at $26 \cdot 4$ metres, on July 15th at E1 at 2.9 metres, on July 26th at 18.5 metres, and on August 4 th at 3.5 metres. This indicates that while they may occur in numbers at any depth, there is perhaps a tendency for them to be most abundant round about $20-25$ metres.

I give below the sizes of the mackerel post-larvæ caught at each depth on two occasions showing that there is no differentiation of size with depth.

July 6th, 1926

Surface

$3 \cdot 3$ metres

$7 \cdot 8 \quad$,

$20 \cdot 9 \quad$,

$24 \cdot 7$,

$37 \cdot 2$,

August 4th, 1926

Surface (i)

3.5 metres

$9 \cdot 5 \quad$,

$22 \cdot 2$,

28.2 ,

39.4 ,

\begin{tabular}{|c|c|c|c|c|c|c|c|}
\hline \multicolumn{8}{|c|}{ Length in millimetres. } \\
\hline 4 & 5 & 6 & 7 & 8 & 9 & 10 & 11 \\
\hline - & 3 & 1 & 1 & 1 & - & - & \\
\hline \multicolumn{2}{|c|}{20} & 18 & 12 & 9 & 7 & 2 & \\
\hline 16 & 12 & 29 & 8 & 3 & 2 & 1 & \\
\hline 6 & 69 & 54 & 25 & 4 & 3 & - & \\
\hline 9 & 22 & 90 & 45 & 14 & 2 & - & \\
\hline 5 & 27 & 52 & 15 & 4 & 1 & - & \\
\hline
\end{tabular}

Ratio, oblique hauls with ring-trawl $:$ bottom plankton net $=7 \cdot 3: 1$. 


\section{ZEID E.}

\section{Zeus faber L. (John Dory).}

Only four post-larvæ of this species were taken ; one of $4 \frac{1}{2} \mathrm{~mm}$. at E1 from 13.7 metres on July 15th, and one of $5 \mathrm{~mm}$. from 9.5 metres and two of 4 and $4 \frac{1}{2} \mathrm{~mm}$. from $28 \cdot 2$ metres on August 4 th.

\section{GOBIID $\approx$ (Gobies).}

On occasions when post-larval gobies were at all numerous they were always taken from below about 25 metres (Fig. 5). This agrees with the results for the year 1925, but in the few collections made in 1924 they appeared to be higher in the water. It was remarked previously (1, p. 108) that by comparison with the numbers taken in 1924 there was an amazing absence of young gobies in 1925. During the course of a series of hauls taken during 24 hours on June 3rd-4th in 1926 however, the numbers of post-larval gobies show a great increase at night, there being more than eight times as many caught in the dark as in the daytime. In 1925 , also from observations made two nights in succession (2, p. 398), it appears that the post-larval gobies were very much more abundant at night than in the daytime. This at once suggests that actually, although not present in the catches from the upper layers as abundantly as in 1924, they were not really scarce, but were living in the daytime in layers deeper than those sampled by the net in 1925 and 1926. Evidence obtained by means of the bottom plankton net gives a striking confirmation to this suggestion. Actually throughout the year on an average the bottom plankton net caught 298 times as many post-larval gobies as the oblique hauls with the ring-trawl. The greatest number of post-larval gobies were taken in July when the average half-hourly catch $(\times 8.5)$ with the bottom plankton net was 3247 as against $2 \cdot 1$ for the same time with the ring-trawl hauled obliquely through the upper water layers. This would seem to afford definite proof that normally in the daytime, at any rate in 1925, 1926, and 1927, the post-larval gobies, 4-12 mm. in length (species unidentified), live in the water layers immediately adjacent to the bottom. What was the cause for the unusual behaviour in 1924 when the post-larvæ were high in the water is not known, but there is evidence that other plankton animals behaved differently that year from the two succeeding years.

Ratio, oblique hauls with ring-trawl : bottom plankton net=1 : 297.8.

\section{Lebetus scoRpioides (Coll.).}

Post-larvæ of this species were never abundant, but as in previous records there was a tendency for them to keep to the deeper layers. 
Actually 20 were caught between the surface and 10 metres, 7 between 10 and 20 metres, 49 between 20 and 30 metres, and 52 between 30 and 45 metres. They were most abundant on August 4th, and Table 4 definitely shows that they were most numerous below 20 metres and that their numbers were still increasing with depth.

Ratio, oblique hauls with ring-trawl : bottom plankton net $=3 \cdot 3: 1$.

\section{BLENNIID $\mathbb{E}$ (Blennies).}

The three species of blennies whose post-larvæ appeared in the 1926 catches were B. ocellaris (L.), B. pholis (L.), and B. gattorugine (L.).
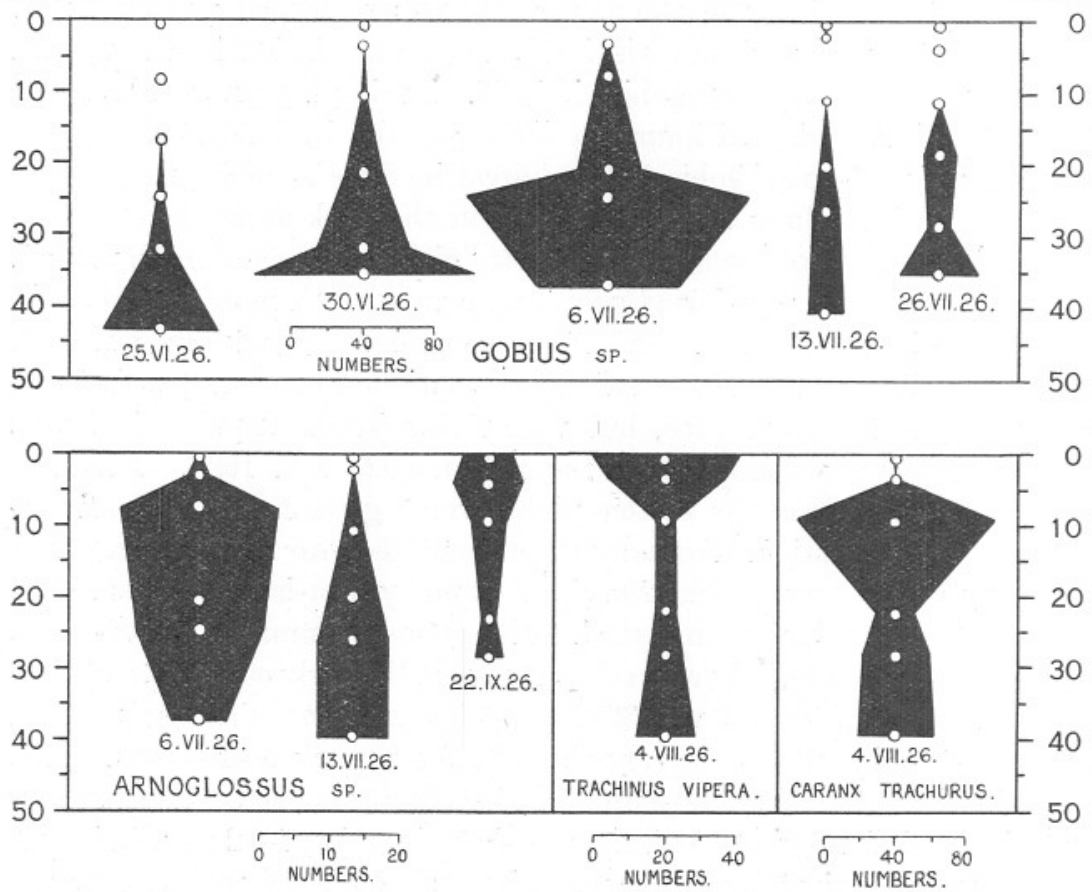

FIG. 5.-The vertical distribution of post-larvæ of the above species on the dates given. The white spots and black circles indicate the "average depths" at which hauls were taken.

Although few were taken in previous years the conclusions were $(1$, p. 135), "it would appear that on the whole the majority of the postlarvæ of the above three species frequented the water layers above a depth of 25 metres right up to the surface itself."

In 1926 the only species whose post-larvæ appeared in significant numbers was Blennius gattorugine, and Figure 4, p. 658, shows very clearly 
that post-larvæ of this form, 5-10 mm. in length, definitely prefer the actual surface layers.

Ratio, oblique hauls with ring-trawl : bottom plankton net $=B$. pholis $0 \cdot 6: 1 ;$ B. gattorugine $0 \cdot 7: 1$,

\section{Chirolophis galerita L. (Yarrell's Blenny).}

Four post-larvæ of this species occurred in the catches of 1925 (1, p. 154) on April 2nd and April 8th, but their presence was not mentioned in the text. These four specimens, $4-5 \mathrm{~mm}$. in length, came from 5 metres, 12.5 metres (2), and 32.5 metres. In 1926 none were caught during the observations made on vertical distribution.

Ratio, oblique hauls with ring-trawl : bottom plankton net $=2 \cdot 2: 1$.

\section{Centronotus gunnellus Bl. Schn. (Gunnell).}

Two post-larvæ of this species, 12 and $18 \mathrm{~mm}$. in length, were caught from 22.4 metres on April 9th, 1926.

\section{TRIGLID $\mathrm{E}$ (Gurnards).}

Post-larval gurnards, probably comprising Trigla gurnardus L. $T$. cuculus L., T. hirundo Bl, and T. Tineata L., were not very numerous in the 1926 collections, but the few present tend to confirm the previous conclusions that post-larvæ, mostly 5-11 $\mathrm{mm}$. in length, generally begin to become abundant at about 15 metres.

Ratio, oblique hauls with ring-trawl : bottom plankton net $=2 \cdot 5: 1$.

\section{COTTID $A$.}

\section{Cottus Bubalis (Euphr.), (Bullhead).}

Only 17 post-larvæ of this species occurred in the 1926 collections, and of these 12 were caught from below 20 metres, which confirms the results of the few caught in the previous years.

Ratio, oblique hauls with ring-trawl : bottom plankton net $=6 \cdot 7: 1$.

\section{CYCLOPTERID $\approx$.}

\section{LiPARIS Montagui (Donov.), (Montagu's Sucker).}

Only three post-larvæ of this species were taken, one from $21 \cdot 6$ metres, one from 39 metres, and one from 41 metres (Table 1.). Previous evidence, though slight, pointed to this being a deep-living form.

Only four were taken in the bottom plankton net. 


\section{GOBIESOCID Æ.}

Lepadogaster bimaculatus (Penn.), (Doubly spotted Sucker).

Twenty-four post-larvæ of this species were taken and of these 11 were caught between 20 and 30 metres, and 13 between 30 and 45 metres. This confirms the previous indications, and results with the bottom plankton net point to their living very near the bottom, as do also the 24-hour series on June 3rd-4th, 1926, when the post-larvæ showed a definite increase in numbers at night.

Ratio, oblique hauls with ring-trawl : bottom plankton net $=1: 76 \cdot 8$.

\section{LOPHIID $Æ$.}

LopHIUS PISCATORIUS (L.), (Angler).

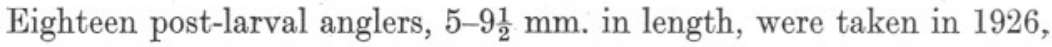
and of these 2 occurred between the surface and 10 metres, 2 between 10 and 20 metres, 7 between 20 and 30 metres, 4 between 30 and 40 metres, and 3 below 40 metres.

\section{SUMMARY.}

1. From April to September in 1926 a further series of collections were made with the 2-metre ring-trawl in water 54 metres deep off Plymouth, to supplement the results already published (1) on the vertical distribution of post-larvæ of teleostean fishes in the daylight.

2. From June, 1927, to May, 1928, collections were made with a bottom plankton net for comparison with catches made with oblique hauls with the ring-trawl during the same period.

3 . The results confirm to a very large extent the conclusions already published as to the vertical distribution of the post-larvæ of many of our commoner fish; and the bottom plankton net collections together with the series of 24-hour observations already published ( 2 and 3 ), throw further light on the behaviour of such species as Gadus minutus and the Gobies.

4. The true distribution of the post-larvæ of the clupeids, the sprat and the pilchard, in the daytime remains yet to be discovered.

5. On page 642 is given a scheme in which the fish are classified as to their vertical distribution on a sunny day as far as is possible from the data obtained.

6. It is remarked that there is a definite difference in the behaviour of the post-larvæ of certain spring-spawning fish as opposed to those of summer-spawners. Most of the post-larvæ of spring-spawners keep to the layers below about 15 metres, while most of the latter are to be found above 25 metres up to the very surface itself. 


\section{REFERENCES.}

1. Russeld, F. S. The Vertical Distribution of Marine Macroplankton. II. The pelagic Young of Teleostean Fishes in the Daytime in the Plymouth Area, with a note on the Eggs of certain Species. Journ. Mar. Biol. Assoc., N.S., Vol. XIV, No. 1, pp. 101-159. 1926.

2. - III. Diurnal Observations on the Pelagic Young of Teleostean Fishes in the Plymouth Area. Ibid., Vol. XIV, No. 2, pp. 387-414. 1926.

3. VIII. Further Observations on the Diurnal Behaviour of the Pelagic Young of Teleostean Fishes in the Plymouth Area. Ibid., Vol. XV, No. 3, pp. 829-850. 1928.

4. VII. Observations on the Behaviour of Calanus finmarchicus. Ibid., Vol. XV, No. 2, pp. 429-454. 1928.

5. — A Net for Catching Plankton near the Bottom. Ibid., Vol. XV, No. 1, p. 105. 1928. 
METRES

METRES
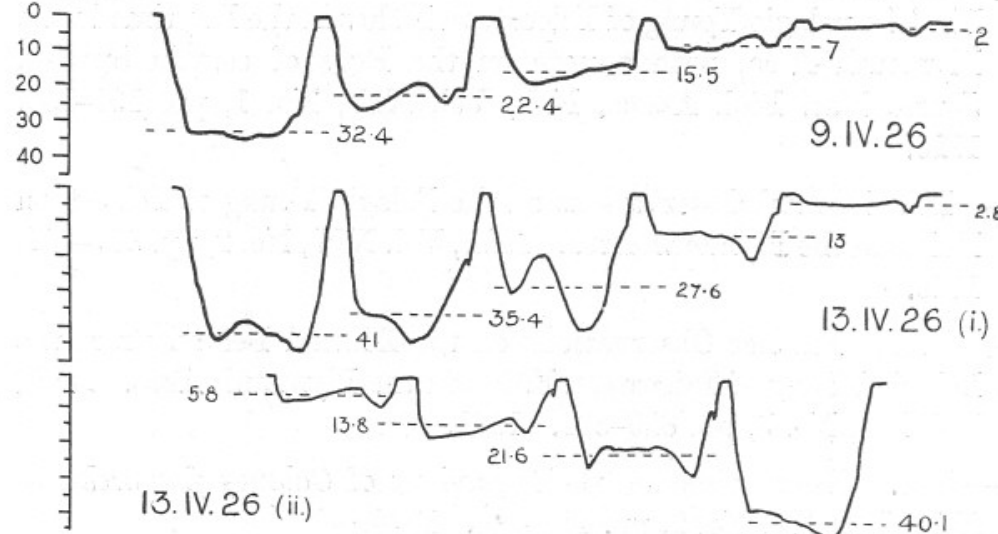

F 0

9.IV.26

- 20

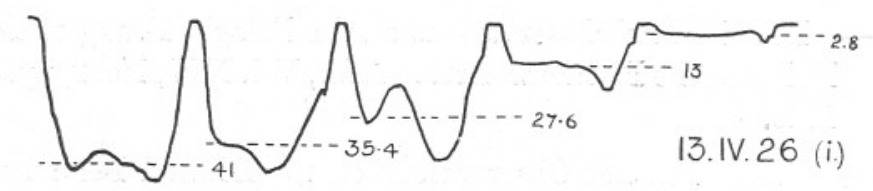

13.IV. 26 (i.)

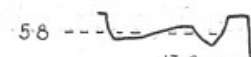

13. IV. 26 (ii.)
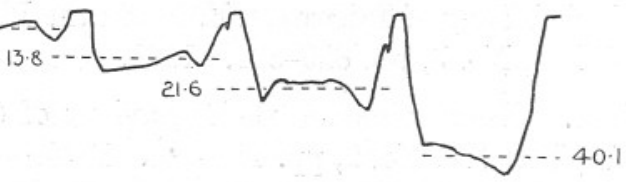

$=40$

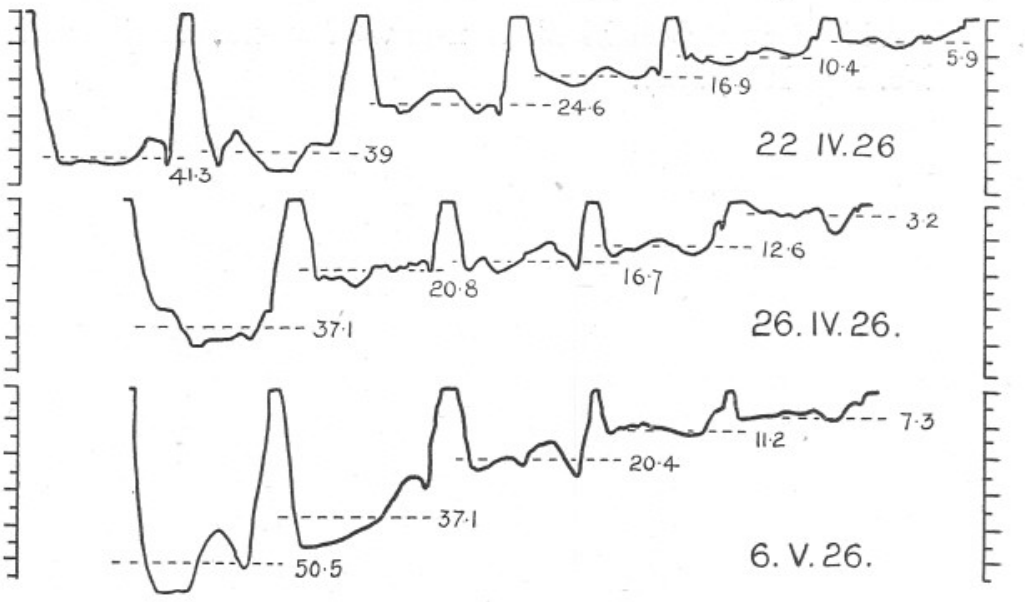

$\exists$
$\exists$
$\exists$

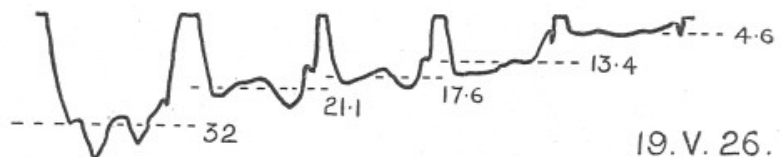

19. V. 26.

FIG. 6.-The series of curves given by the depth-recorder indicating the path of the net through the water for each haul on the dates given. The net enters the water on the right-hand side of each curve. The dotted lines indicate the calculated " average depth." 
METRES.

METRES.
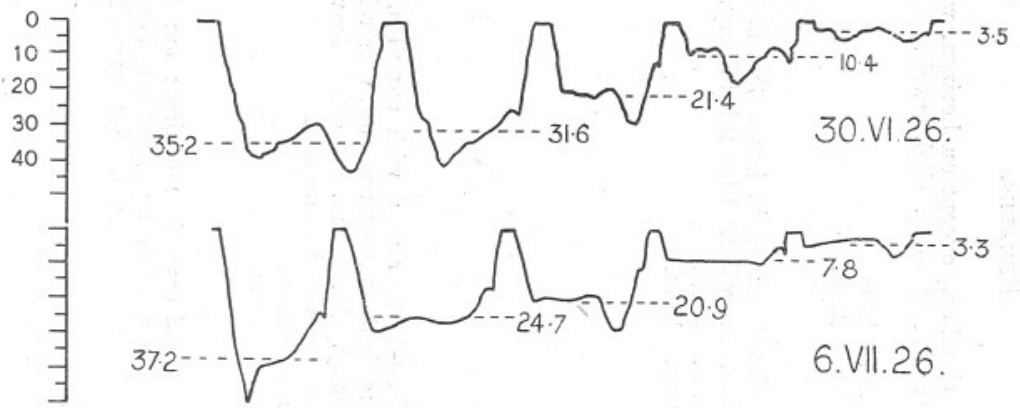

${ }^{0}$
$=10$
$E$
$=30$
$={ }^{30}$

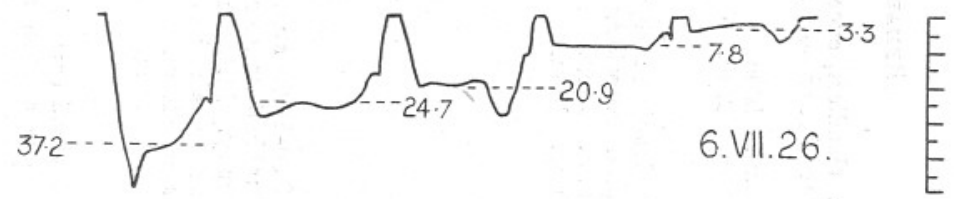

$\exists$
$\exists$
$\exists$
$\exists$
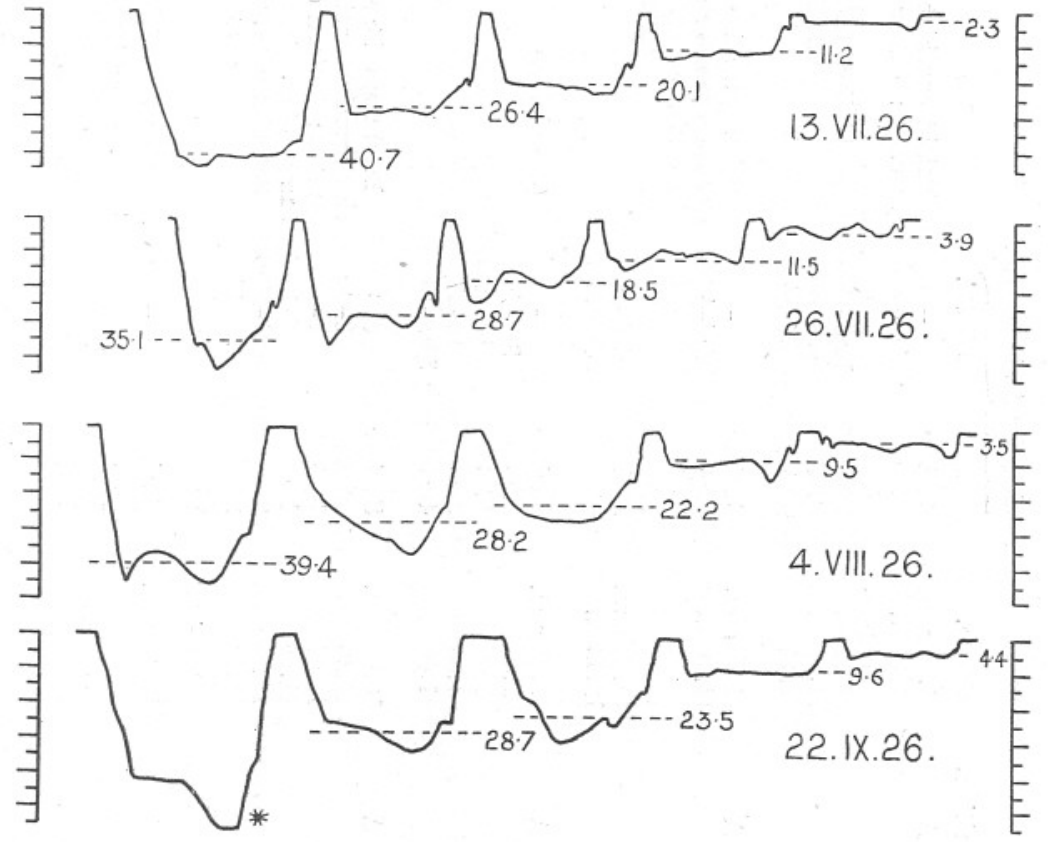

FIG. 7.-The series of curves given by the depth-recorder indicating the path of the net through the water for each haul on the dates given. The net enters the water on the right-hand side of each curve. The dotted lines indicate the calculated "average depth." * 22. ix. 26: Struck bottom. 


\begin{tabular}{|c|c|c|c|c|c|}
\hline & & & & & ReMaRKs. \\
\hline April 9th & A & $\begin{array}{l}11.29 \text { a.m. } \\
11.46 \text { ". } \\
12.3 \text { p.m. } \\
12.22 \text { ", } \\
12.42 \text { ", } \\
1.04 \text {," }\end{array}$ & $\begin{array}{l}\text { Surface } \\
2 \\
7 \\
15 \cdot 5 \\
22 \cdot 4 \\
32 \cdot 4\end{array}$ & $\begin{array}{c}- \\
1 \cdot 5-4 \\
4-9 \\
12 \cdot 5-18 \cdot 5 \\
18-25 \cdot 5 \\
27-34\end{array}$ & $\begin{array}{l}\text { Bright sunshine; cloudless, except on horizon, which was hazy. } \\
\text { Sea calm; but surface not smooth ; slight swell. Wind light, from } \\
\text { west. } \\
\text { Secchi disc } 11.27 \text { a.m. } 10 \mathrm{~m} . \\
1.25 \text { p.m. } 12 \mathrm{~m} .\end{array}$ \\
\hline April 13th (i) & A & $\begin{array}{l}11.3 \text { a.m. } \\
11.21 \text { ", } \\
11.39 \text { ", } \\
11.59 \text { ", } \\
12.18 \text { p.m. } \\
12.38 \text {," }\end{array}$ & $\begin{array}{l}\text { Surface } \\
2 \cdot 8 \\
13 \\
27 \cdot 6 \\
35 \cdot 4 \\
41\end{array}$ & $\begin{array}{c}- \\
2 \cdot 5-4 \\
11-18 \\
18-38 \\
25-42 \\
37 \cdot 5-46\end{array}$ & $\begin{array}{l}\text { Bright sunshine; cloudless ; slight haze. Sea flat calm ; surface } \\
\text { smooth without ripples. No wind. Like this all day. } \\
\text { Secchi disc } 11.00 \text { a.m. } 12 \mathrm{~m} \text {. } \\
12.55 \text { p.m. } 10 \mathrm{~m} \text {. }\end{array}$ \\
\hline April 13th (ii) & A & $\begin{array}{l}2.51 \mathrm{p} . \mathrm{m}, \\
2.35, \\
2.17, \\
1.58, \\
1.40,\end{array}$ & $\begin{array}{l}\text { Surface } \\
5 \cdot 8 \\
13 \cdot 8 \\
21 \cdot 6 \\
40 \cdot 1\end{array}$ & $\begin{array}{l}3 \cdot 5-7 \cdot 5 \\
10-16 \cdot 5 \\
19-27 \\
36 \cdot 5-45\end{array}$ & (See above.) \\
\hline April 22nd & A & $\begin{array}{l}10.18 \text { a.m. } \\
10.35 \quad, \\
10.56 \text { ", } \\
11.15 \quad " \\
11.35 \text { ", } \\
11.59 \text {,"m. } \\
12.22 \text { p.m. }\end{array}$ & $\begin{array}{l}\text { Surface } \\
5 \cdot 9 \\
10 \cdot 4 \\
16 \cdot 9 \\
24 \cdot 6 \\
39 \\
41 \cdot 3\end{array}$ & $\begin{array}{l}0-3 \\
3-8 \\
6-13 \\
15-19 \cdot 5 \\
21-27 \cdot 5 \\
35-45 \\
35-44\end{array}$ & $\begin{array}{l}\text { Bright sunshine } 8.30-10 . c 0 \text { a.m. ; with cumulus. At } 10.15 \text { sky } \\
\text { cloudless for considerable distance round sun, with a little high cirro- } \\
\text { stratus : horizon cloudy. } 11.10 \text { a.m. sun clouded over : } 11.59 \text { a.m. } \\
\text { sun shining. Sea surface calm but broken. } \\
\text { Secchi disc } 11.12 \text { a.m. } 10 \mathrm{~m} \text {. } \\
1.40,11 \mathrm{~m} \text {. }\end{array}$ \\
\hline April 26th & A & $\begin{array}{l}10.3 \text { a.m. } \\
10.21 \text {," } \\
10.38, " \\
10.52, " \\
11.12, " \\
11.35, "\end{array}$ & $\begin{array}{l}\text { Surface } \\
3 \cdot 2 \\
12 \cdot 6 \\
16 \cdot 7 \\
20 \cdot 8 \\
37 \cdot 1\end{array}$ & $\begin{array}{c}- \\
1-8 \\
7 \cdot 5-16 \\
11 \cdot 5-20 \\
18-25 \\
31 \cdot 5-40 \cdot 5\end{array}$ & $\begin{array}{l}\text { Dull with thickish cloud early in morning; sun trying to breal } \\
\text { through later ; sun shone at } 10.40 \text { a.m., but was soon covered again, } \\
\text { showing only dimly for rest of hauls. Sea surface choppy ; stiff } \\
\text { N.W. breeze. } \\
\text { Secchi disc } 10.00 \text { a.m. } 11.5 \mathrm{~m} \text {. } \\
\qquad 12.45 \text { p.m. } 13 \mathrm{~m} \text {. }\end{array}$ \\
\hline
\end{tabular}




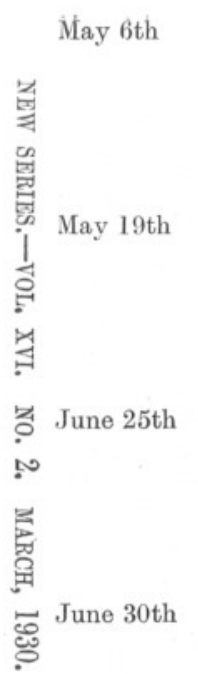

A

$\begin{array}{ll}10.8 \text { a.m. } & \text { Surface } \\ 10.26, & 7 \cdot 3 \\ 10 \cdot 44, & 11 \cdot 2 \\ 11.4 \% & 20 \cdot 4 \\ 11.27 \% & 37 \cdot 1 \\ 11.48 \% & 50 \cdot 5\end{array}$

A

9.32 a.m.
9.53 ",
10.14 ",
10.36 ",
10.56 "
11.22,

A

$\begin{array}{cc}9.52 \text { a.m. } & \text { Surface】 } \\ 10.10, & 8 \cdot 2 \ddagger\end{array}$

Surface

$4 \cdot 6$

$4 \cdot 6$
$13 \cdot 4$

$17 \cdot 6$

$21 \cdot 1$

21.

$10.29 " \quad 16.9 \%$

$10.49, \quad 24 \cdot 6$ \%

$11 \cdot 10, \quad 32 \%$

$11.31, \quad 43 \cdot 1 \ddagger$

L4

10.57 a.m. Surface

$11 \cdot 13, \quad 3 \cdot 6$

11.30 ",

11.46 ,"

$\begin{array}{ll}12.24 \text {, }, & 31 \cdot 6 \\ & 35 \cdot 2\end{array}$

July 6 th

$\infty$

$\begin{array}{ccc}9.56 \text { a.m. } & \text { Surface } & - \\ 10.11, & 3 \cdot 3 & 2-6 \\ 10.28, & 7 \cdot 9 & 5-9 \\ 10.45, & 20 \cdot 9 & 18-28 \\ 11.5 \% & 24 \cdot 7 & 17-28 \cdot 5 \\ 11.28, & 37 \cdot 2 & 25-50 \cdot 5\end{array}$

4-9 $6 \cdot 5-13$

15-25 25-45 $40-58$ †

$3-5$

$7-16 \cdot 5$

$16-25$

$16-25$
$25-40$

6-9

$15-20$
$19-27$

$31-33$

$39-49 \S$

$-$

$2-5 \cdot 5$

7-16

18-28 ,

25-39

$30-42 \cdot 5$
Very thick clouds; dull; visibility fair. Sea calm, but surface broken by breeze.

Sechi dise 11.47 a.m. $14 . \mathrm{m}$.

Weather from sunrise to start of work close, sky overcast. Sun tried to come through at 10.00 a.m., but only shone brightly at last haul. Wind very slight; sea surface with slight ripple.

Secchi dise $9 \cdot 25$ a.m. $13 \mathrm{~m}$.

Cloudless ; slight haze ; no wind ; sea surface glass calm.

Secchi dise 9.50 a.m. $19 \frac{1}{2} \mathrm{~m}$.

$$
12.00 \text { p.m. } 20 \frac{1}{2} \mathrm{~m} \text {. }
$$

A little very high cirrus, otherwise cloudless. Bright sunshine; slight haze. Stiff east wind; sea moderate.

* All hauls were of 10 minutes' duration, the time given being the start of the haul.

\$ Drum of depth-recorder not screwed home ; 4 metres have been added to recorded depth. $\dagger$ Net struck bottom.

$\S$ Wire broke; net fished for $13 \frac{1}{2}$ minutes. 
Fishing depths in metres.

Date.

July I3th

July 15th

July 26 th

August 4th

September 22nd
Position.

A

Time.

9.41 a.m.

9.58 ,

10.15,

10.33,

10.53

11.11,

El

10.46 a.m.
11.00,

11.00 ,

11.15,

11.53,

12.10 p.m.

12.31 ",

A

10.16 a.m

10.32 ,

10.49,

$11 \cdot 6$,

11.22 ,"

11.41 ",

A

10.00

10.18 ",

10.37,

10.56,

11.17,

11.36 ",

A $\overbrace{\text { Average. Limits. }}$

Surface

1.20 p.m. Surface

$1.40, \quad 4.4$

1.57

1.57 ,

2.18 ,

2.39 , ,

2.58,
$2 \cdot 3$

$11 \cdot 2$

$20 \cdot 1$

$26 \cdot 4$

$40 \cdot 7$

Surface

$2 \cdot 9$

$6 \cdot 6$

$13 \cdot 7$

$21 \cdot 5$

$34 \cdot 1$

49

Surface

$3 \cdot 9$

$11 \cdot 5$

$18 \cdot 5$

28.7

Surface

$3 \cdot 5$

$9 \cdot 5$

$22 \cdot 2$

$28 \cdot 2$

$39 \cdot 4$

Surface

2-4

10-12

15-22

$20-29$

$35 \cdot 5-44$

$4 \cdot 4$
$9 \cdot 6$

$9 \cdot 6$
$23 \cdot 5$

$28 \cdot 7$

$$
1 \cdot 5-4 \cdot 5
$$

$1 \cdot 5-4 \cdot 5$
$4-8 \cdot 5$

$11 \cdot 5-19$

$17-23.5$

29-40

44-57

$-$

2-6

10-14

14-24

$23-35 \cdot 5$

25-43

2.5-6

7-13

$14 \cdot 5-25$

21-35

$31 \cdot 5-43$

$-$

$2-5$

$2-5$
$9-10$

$15 \cdot 5-30$

$25-33 \cdot 5$

Remarks.

Cloudless; brilliant sunshine; haze in distance. Fresh easterly wind; sea surface choppy.

Secchi disc 11.30 a.m. $13 \mathrm{~m}$.

Sun partially obscured by hazy cloud; visibility poor.

Secchi dise 10.35 a.m. $12 \mathrm{~m}$.

$$
1.30 \text { p.m. } 13 \mathrm{~m} \text {. }
$$

|| Net struck bottom.

Very dull and overcast at start of day, with heavy clouds; 9.45 a.m. clouds broke up and sun came out bright; remained out till 11.15 a.m.; 11.40 a.m. raining. Sea surface calm, but rippled.

Secchi disc 12.00 p.m. $12 \mathrm{~m}$.

Bright sunshine; cloudless ; no haze. Sea surface choppy ; slight swell.

Secchi disc 12.55 p.m. $9 \mathrm{~m}$.

Weather dull; at 1.40 p.m. sun was shining through thin cloud

for short time. Sea calm. 
TABLE 1.

April 9th, 1926

April 13th, 1926 (i)

April 13th, 1926 (ii)

April 22nd, 1926

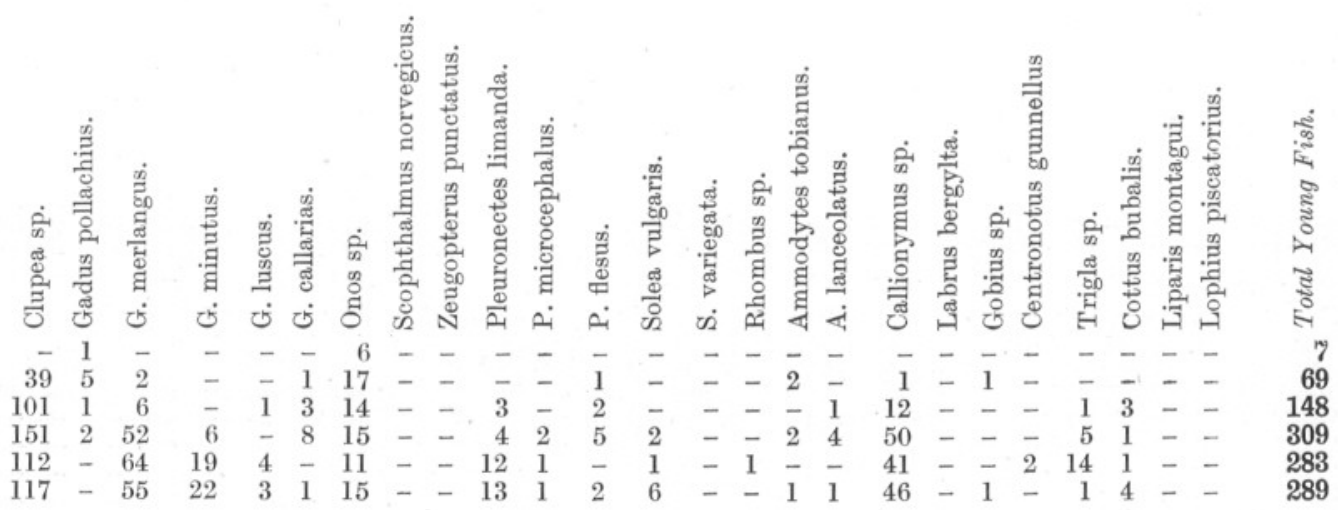

$-\overline{-}-1 \div-\overline{-}$
$\overline{1}-\overline{-}-\overline{-}$

$27 \cdot 6$

$\begin{array}{rrrr}2 & 2 & - \\ 87 & 4 & 4 \\ 55 & 3 & 54\end{array}$

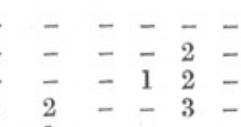

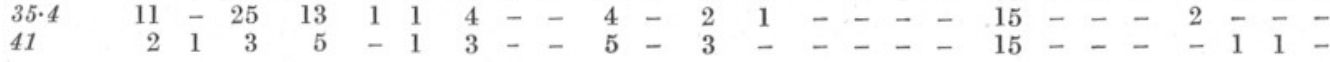

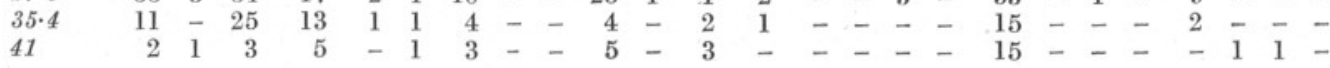

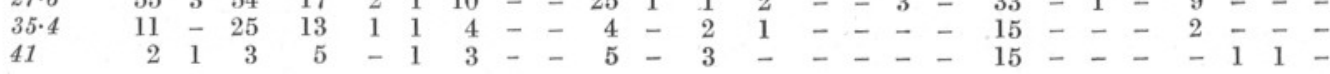

- - - - - -

$\stackrel{2}{13}$

79

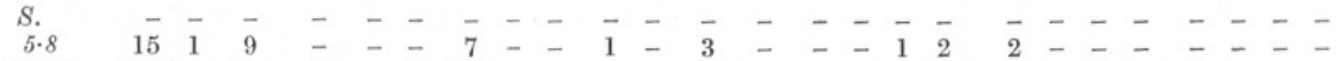

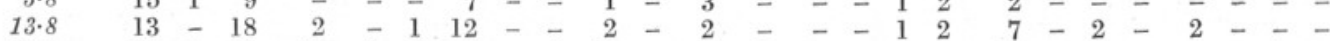

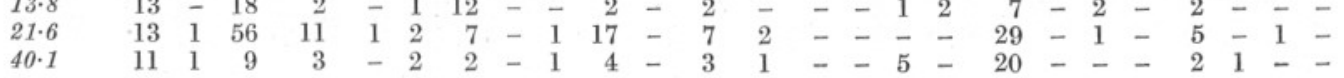

$4 \overline{1}$

64

154

$\begin{array}{rrrrrrrrrrrrrrrrrrrrrrrrrrr}S . & 1 & 1 & - & - & - & - & 4 & - & - & - & - & - & - & - & - & - & - & - & - & - & - & - & - & - & - & 6 \\ 5 \cdot 9 & 2 & - & 2 & - & - & - & - & - & - & - & - & 1 & - & - & - & - & - & - & - & - & - & - & - & - & - & 5 \\ 10 \cdot 4 & 12 & 3 & 2 & 2 & 1 & - & 1 & - & - & 5 & - & 10 & 1 & - & - & - & 1 & 8 & - & - & - & 2 & - & - & - & 48 \\ 16 \cdot 9 & 51 & - & 45 & 31 & 3 & - & 1 & 1 & 1 & 41 & 4 & 8 & 8 & 12 & - & - & 2 & 77 & - & 3 & - & 5 & - & - & - & 293 \\ 24 \cdot 6 & 30 & 1 & 51 & 132 & 13 & - & 3 & 1 & 4 & 49 & 6 & 7 & 11 & 20 & - & 1 & - & 186 & 2 & 3 & - & 6 & 1 & - & - & 524 \\ 39 & 10 & - & 21 & 144 & 5 & - & 3 & 2 & - & 10 & 2 & 2 & 10 & 5 & - & 1 & - & 110 & - & 2 & - & - & - & 1 & 1 & 329 \\ 41 \cdot 3 & 17 & 4 & 13 & 131 & 6 & - & - & 2 & - & 11 & 3 & 1 & 18 & 5 & - & 1 & 2 & 95 & - & 6 & - & 1 & 3 & - & - & 319\end{array}$ 


\section{TABLE 2.}

April 26th, 1926

May 6th, 1926

May 19th, 1926

June 25th, 1926

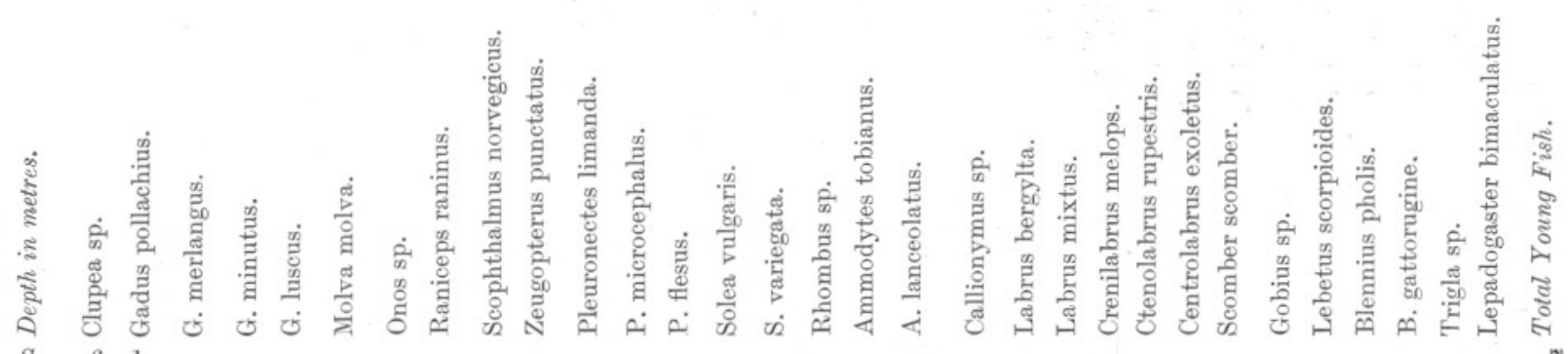

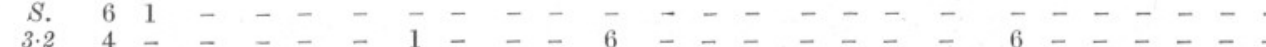

$12.647-12131-5-11116-100-7-5$

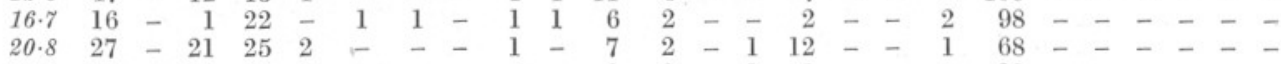

$\begin{array}{rrrrrr}37 \cdot 1 & 9 & \overline{2} & 2 & 23\end{array}$

$33---\ldots---2-169$

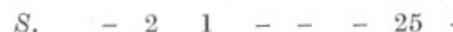

$\begin{array}{rrrrrrrrr}- & - & - & - & - & - & - & - & - \\ 1 & - & 1 & \overline{1} & - & - & - & - & - \\ 1 & - & 2 & 5 & - & - & - & 1 & 1 \\ 2 & - & 46 & 22 & 2 & - & - & - & - \\ 1 & 2 & 34 & 3 & - & 1 & 12 & - & -\end{array}$

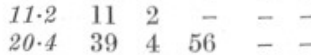

$-12-$ $1-\ldots+\ldots-\ldots-\ldots$

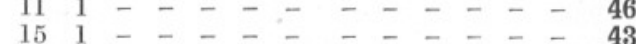
$541-\ldots+\ldots-\ldots 1-246$

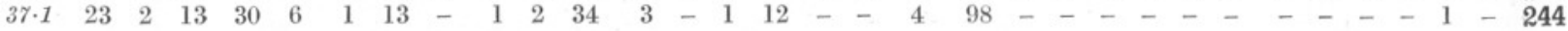

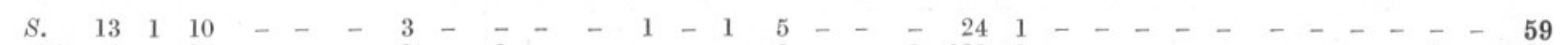

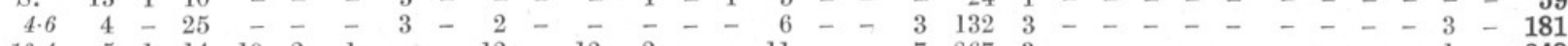

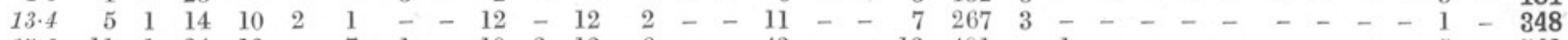

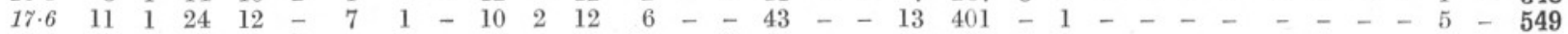

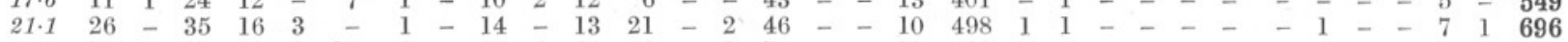
$\begin{array}{llllllllllllllllllllllllllllllllllllll}21.1 & 26 & - & 35 & 16 & 3 & - & 1 & - & 14 & - & 13 & 21 & - & 2 & 46 & - & - & 10 & 498 & 1 & 1 & - & - & - & - & - & - & - & 7 & 1 & 696 \\ 32 & 70 & 1 & 30 & 87 & 2 & 10 & 1 & - & 17 & 6 & 64 & 44 & - & 3 & 74 & - & - & 13 & 493 & - & - & - & - & - & - & - & 2 & - & - & 4 & - & 921\end{array}$

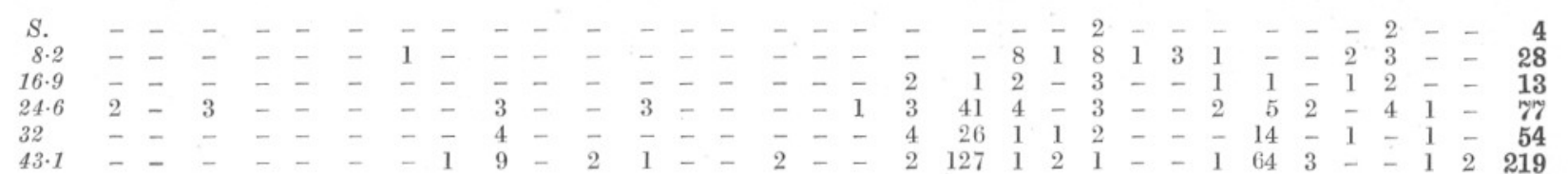


TABLE 3.

June 30th, 1926

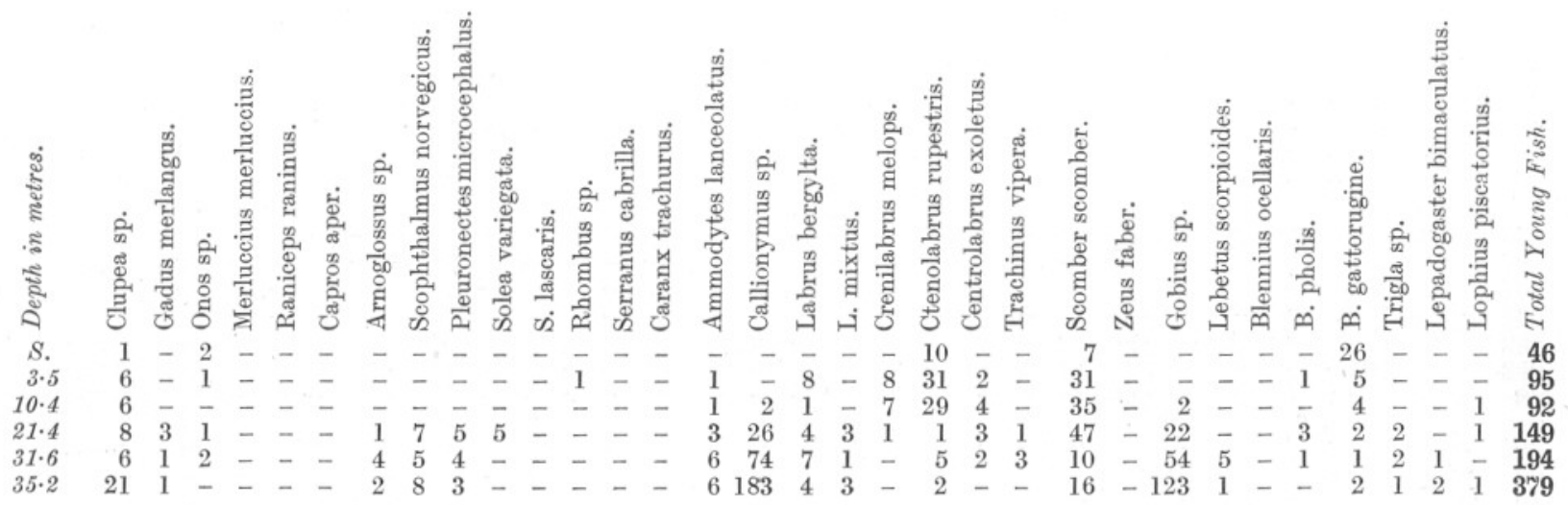

July 6th, 1926

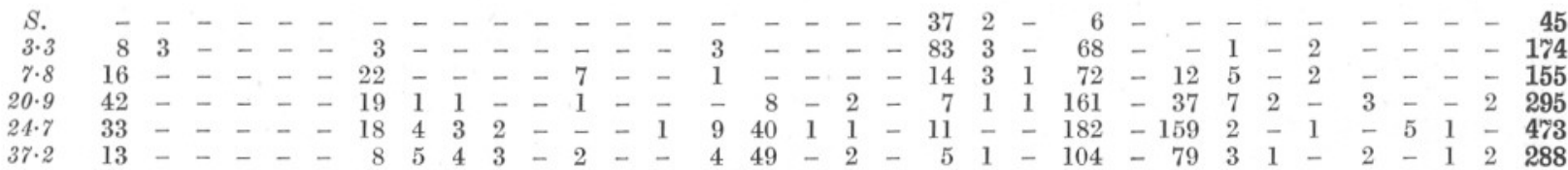

July 13th, 1926

$S$.

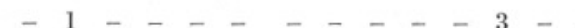
$2 \cdot 3$ $11 \cdot 2$ 16 - - - - - - - $2 \div$

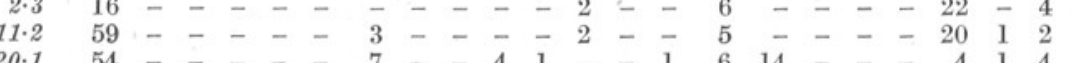

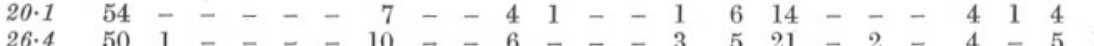

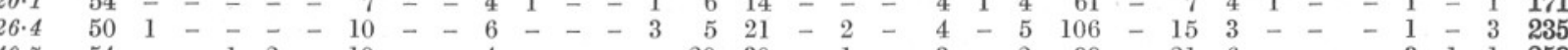
$40.754--12-10--4-\ldots-2030-1-3-299-216-\quad-\quad 3 \quad 11258$

July 15th, 1926

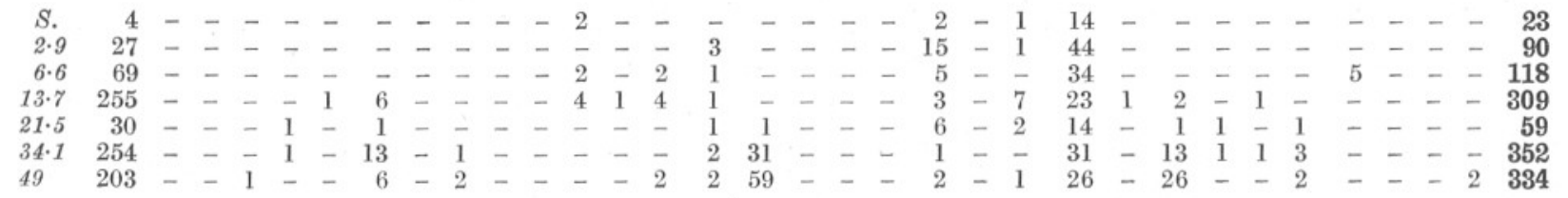

E 1 
Table 4.

July 26th, 1926

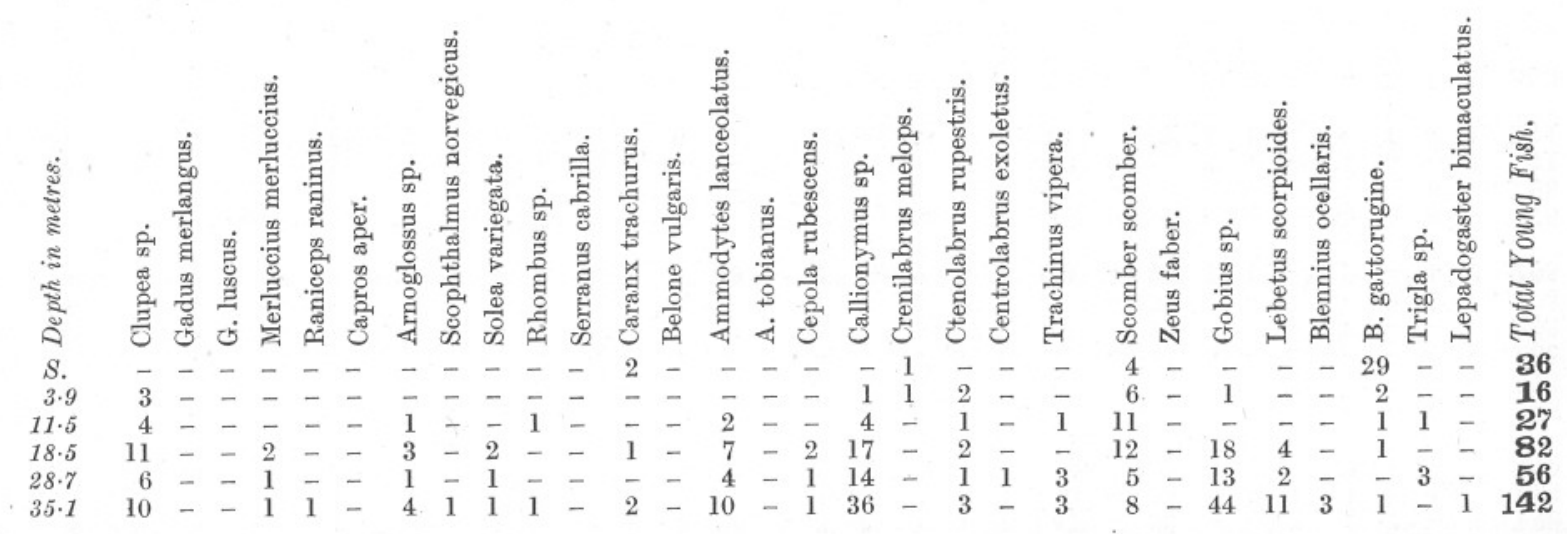

August 4th, 1926

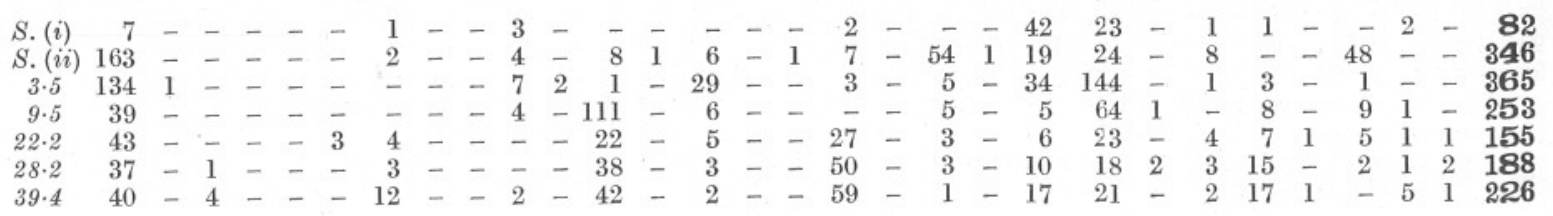

September 22nd, 1926

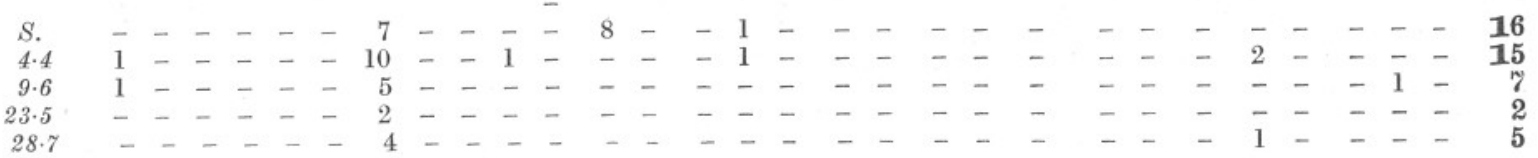


TABLE 5 .

Average Monthly Catches of Bottom Plankton Net, 30-minute Hauls Multiplied by 8.5.

Clupeid sp.

Gadus pollachius

G. merlangus

G. minutus

G. luscus.

Onos sp.

Merluccius merluccius

Arnoglossus sp.

Scophthalmus norvegicus

Zeugopterus punctatus

Pleuronectes limanda

P. flesus

P. microcephalus

Solea vulgaris

S. variegata

S. lutea.

Ammodytes tobianus

A. lanceolatus

Callionymus sp.

Labrus bergylta

L. mixtus

Ctenolabrus rupestris

Crenilabrus melops

Centrolabrus exoletus

Scomber scomber

Gobius sp.

Crystallogobius nillsoni

Lebetus scorpioides

Trachinus vipera

Blennius pholis

B. gattorugine

Chirolophis galerita

Trigla sp.

Cottus bubalis

Lepadogaster bimaculatus

$\begin{array}{rrrrr}\text { Jan. } & \text { Feb. } & \text { March. } & \text { April. } & \text { May. } \\ 35 \cdot 7 & 50 \cdot 2 & 51 \cdot 0 & 65 \cdot 5 & 74 \cdot 0 \\ - & - & - & 0 \cdot 9 & - \\ - & 0 \cdot 9 & 0 \cdot 9 & 9 \cdot 4 & 2 \cdot 5 \\ - & - & 146 \cdot 2 & 1047 \cdot 7 & 1680 \cdot 5 \\ - & 0 \cdot 9 & 1 \cdot 7 & 6 \cdot 0 & 12 \cdot 8 \\ - & - & - & 2 \cdot 6 & 4 \cdot 3 \\ - & - & - & - & - \\ - & - & - & - & - \\ - & - & - & 1 \cdot 7 & 10 \cdot 2 \\ - & - & - & 0 \cdot 9 & 1 \cdot 7 \\ - & - & 0 \cdot 9 & 15 \cdot 3 & 23 \cdot 0 \\ - & - & - & 2 \cdot 6 & - \\ - & - & 1 \cdot 7 & 7 \cdot 7 & 11 \cdot 1 \\ - & - & 8 \cdot 5 & 4 \cdot 3 & 4 \cdot 3 \\ - & - & - & - & 12 \cdot 8 \\ - & - & - & - & - \\ 0 \cdot 9 & 68 \cdot 0 & 1 \cdot 7 & 0 \cdot 9 & 1 \cdot 7 \\ - & 11 \cdot 1 & 1 \cdot 7 & 11 \cdot 1 & - \\ - & - & 6 \cdot 0 & 44 \cdot 2 & 150 \cdot 5 \\ - & - & - & - & - \\ - & - & - & - & - \\ - & - & - & - & - \\ - & - & - & - & - \\ - & - & - & - & - \\ - & - & - & - & - \\ 3 \cdot 4 & 1 \cdot 7 & 5 \cdot 1 & 4 \cdot 3 & 114 \cdot 8 \\ - & - & - & 41 \cdot 7 & 95 \cdot 2 \\ - & - & - & - & - \\ - & - & - & - & - \\ - & - & - & - & - \\ - & - & - & - & - \\ - & 0 \cdot 9 & - & - & - \\ - & - & - & - & 8 \cdot 5 \\ - & - & 1 \cdot 7 & - & - \\ - & - & - & - & 14 \cdot 5\end{array}$

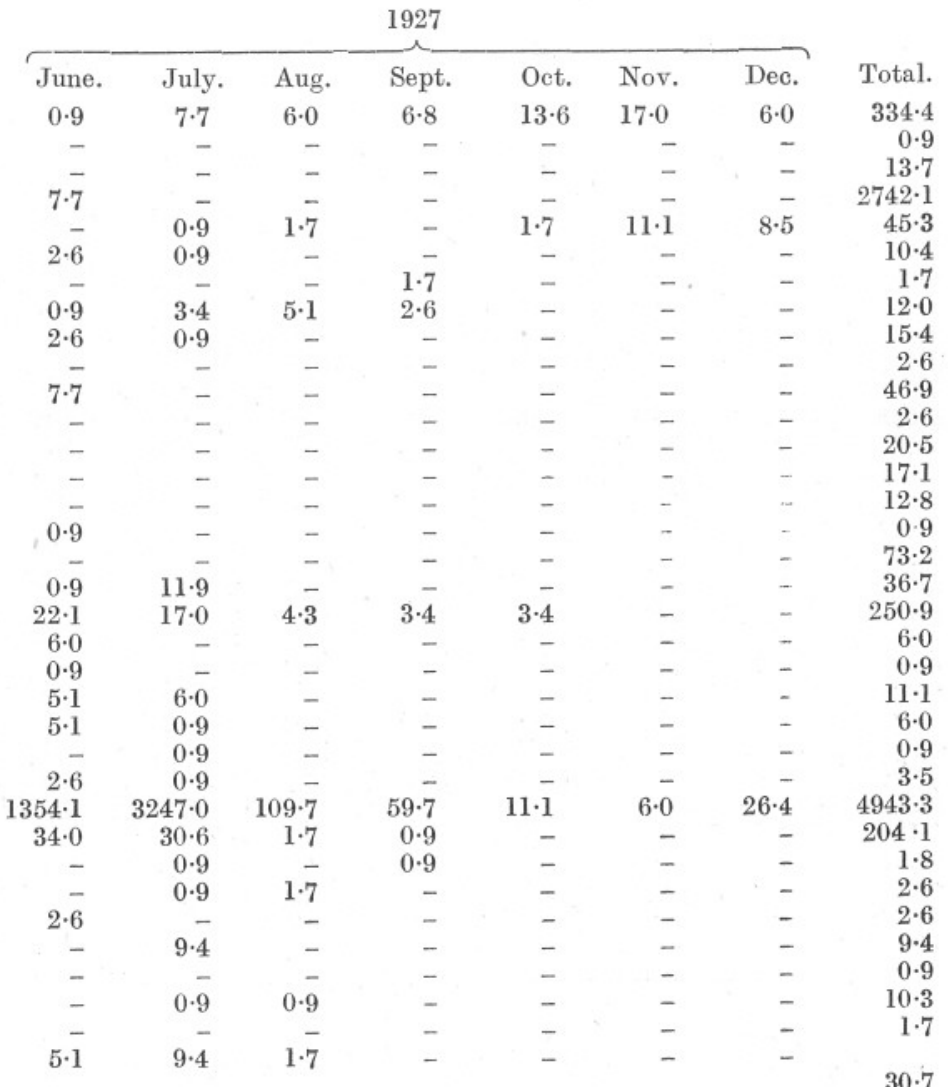


TABLE 6.

Average Monthly Catches in Ring-Trawl, 30-minute Oblique Hauls.

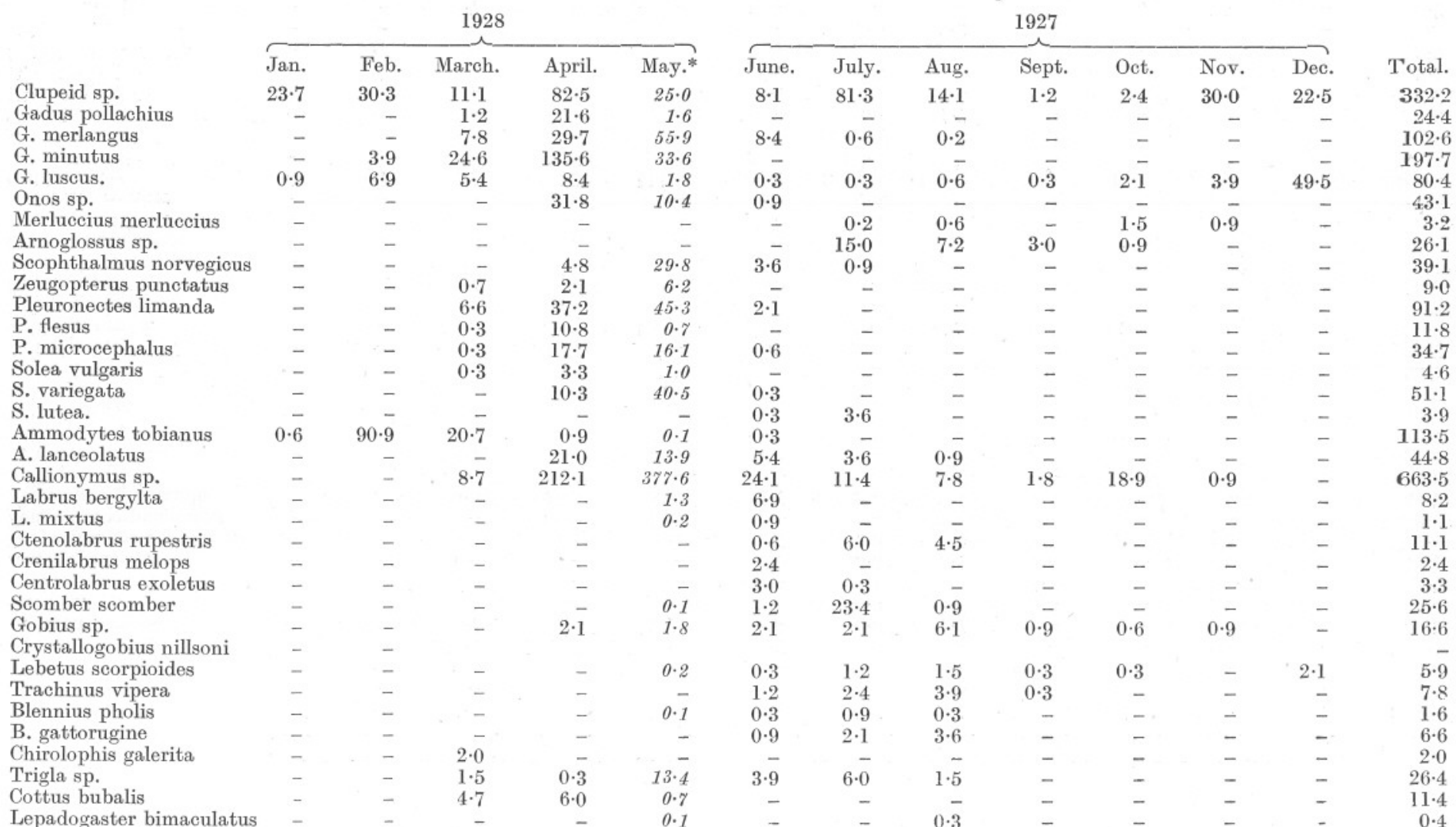

* The figures given here are the average catches per half-hour haul obtained from the years $1924,1925,1926,1927$, and 1929 , the total number of hauls at each station being regarded as one oblique haul in the first three years. 